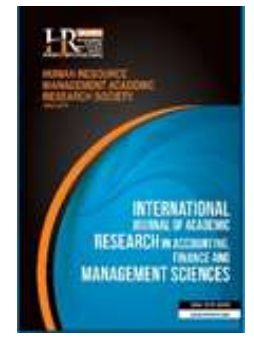

International Journal of Academic Research in Accounting, Finance and Management Sciences

Vol. 9, No.4, October 2019, pp. 182-206

E-ISSN: 2225-8329, P-ISSN: 2308-0337

(C) 2019 HRMARS

www.hrmars.com

To cite this article: Gazzola, P., Amelio, S., Fragkoulis Papagiannis, F., Vătămănescu, E.-M. (2019). Financial Reporting in European Football Teams: A Disclosure Analysis of Player Registrations, International Journal of Academic Research in Accounting, Finance and Management Sciences 9 (4): 182-206

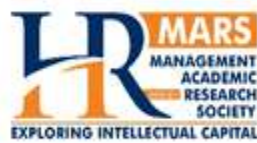

\title{
Financial Reporting in European Football Teams: A Disclosure Analysis of
} Player Registrations

\author{
Patrizia Gazzola ${ }^{1}$, Stefano Amelio ${ }^{2}$, \\ Fragkoulis Papagiannis ${ }^{3}$, Elena-Mădălina Vătămănescu ${ }^{4}$ \\ ${ }^{1}$ Department of Economics, University of Insubria, Via Monte Generoso 71, 21100 Varese; Italy \\ ${ }^{1}$ E-mail: patrizia.gazzola@uninsubria.it (Corresponding author) \\ ${ }^{2}$ Department of Business Administration, Finance and Law (DiSEADE), University of Milano-Bicocca, Via Bicocca degli \\ Arcimboldi n. 8, 20126 Milano, Italy, ²E-mail: stefano.amelio@unimib.it \\ ${ }^{3}$ Liverpool Business School, Liverpool John Moores University Redmonds Building, Brownlow Hill Liverpool; U.K., \\ ${ }^{3}$ E-mail: F.Papagiannis@ljmu.ac.uk \\ ${ }^{4}$ National University of Political Studies and Public Administration, Bulevardul Expoziției 30A, Bucharest, Romania, \\ ${ }^{4}$ E-mail: madalina.vatamanescu@facultateademanagement.ro

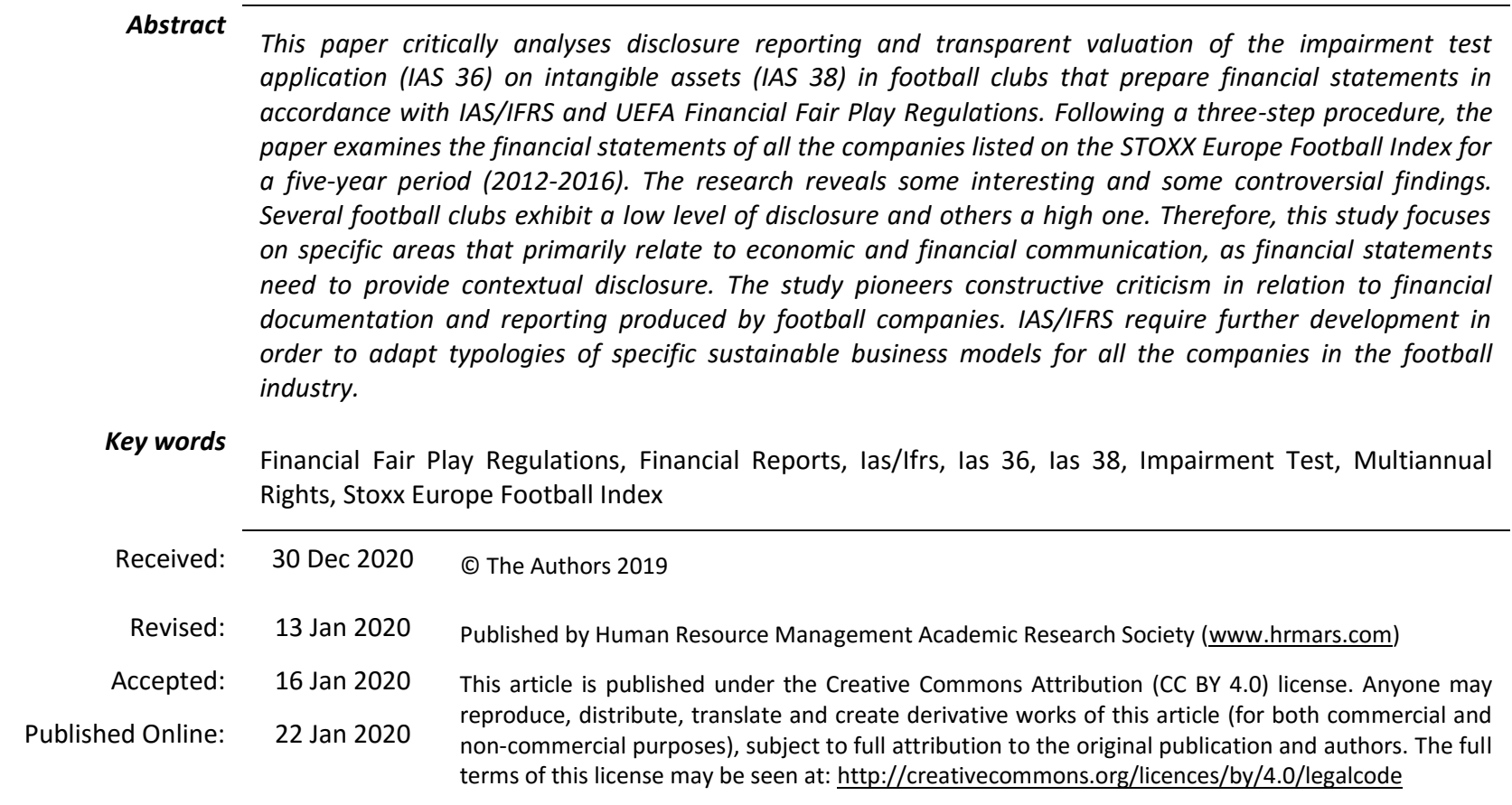

\section{Introduction}

Football is not just a game; it is also a significant international economic market that attracts a wide variety of investors (King, 2017). Historically, football's trajectory seemed to be a rationally controllable phenomenon, one that could almost be represented mathematically (Geeraert et al., 2013; Niemann et al., 2011). However, recent changes in corporate governance that support improved disclosure reporting among stakeholders and corporate social responsibility (CSR) are becoming a critical part of sustainable managerial strategies for the world's largest form of sports entertainment (Blumrodt et al., 2013; Herrmann, 2004; Walters and Chadwick, 2009). 
Football has turned into a new global phenomenon governed by economic and social interests and has been credited as "an integral part of the social and cultural fabric, an event that can solicit the interest of millions of fans, an instrument that increases image and popularity" (Risaliti and Verona, 2012). Giulianotti (2012) underlined football's inherent dimensions, namely social, sport, economic, political, social, historical and cultural. In terms of sport, the search for results has always been a cornerstone. The sport's competition initiated nationally and then, followed by the development of a globalized context, extended to continental and international levels. Subsequently, the economic tier has grown in interest as the business scope has substantively increased, not only due to the economic operators directly involved in the production of the sporting event or the professional world, but also due to several sponsoring companies, which more or less directly contribute to the realisation of football's growth and performance (Rouvrais-Charron and Durand, 2009). In its own right, the political factor has complemented the previous dimensions. For example, state interventions include the following: i) legal regulation of sporting activities; ii) state financial support; and iii) provision of facilities and resources (Taylor, 2013). Moreover, as Breitbarth and Harris (2008) highlighted, the world of football is liable to create political value.

Given the multilevel implications and the magnitude of the football game phenomenon, special emphasis should be placed upon the economic and financial grounds of companies' reports. Specifically, the cumulative revenues for the 'big five' European leagues (Premier League, Bundesliga, La Liga, Serie A, Ligue 1) from the 2010/2011 season was estimated at 8.6 billion euros, and in the 2016/2017 season they reached 14.27 billion euros (Statista, 2018a). Along with the growth of the football clubs' revenues, the transfer fees paid by football clubs to recruit new players have increased significantly over the past few years. The total transfer fee spending of the big- 5 league soccer clubs in year 2010 was 1.5 billion euros, and it reached 5.9 billion euros in 2017 (Statista, 2018b).

In this regard, the treatment of player registrations has become a fundamental accounting problem due to the importance of player registrations with respect to the value of total assets. According to Rowbottom (2002), the debate and therefore the interest in human resources accounting in the context of financial documents, arised in the 1970s (Brummet et al., 1968; Scarpello and Theeke, 1989) then moving towards the intangible assets (Dimitropoulos \& Koumanakos, 2015; Qureshi, 2017; Oliveira et al., 2010; Abdel-Khalik, 2003; Powell, 2003). Currently, they form an accepted common accounting practice in the football industry, obliging leading football corporations to adopt the rules of IAS.

Corporations are obligated by IAS standards to include the cost of acquiring a player's registration as an 'intangible asset' in their financial statements (Guthrie et al., 2012; Stolowy and Jeny-Cazavan, 2001). Amortised over individual players' contract periods, these intangible assets meet the IAS 38 criteria. Thus, football clubs control the players' contracts, and they can recover their value from the players' performances, as well as via transfer fees. As stated by IAS 36 (Husmann and Schmidt, 2008; Mazzi et al., 2016), these intangible assets are subjected to the impairment process (IAS 38.111). International accounting standards added the so-called "Financial Fair Play regulations" several years ago in order to standardize the IAS standards (Preuss, et al., 2014). These regulations became effective from the 2013/14 season (UEFA, 2015) and they are addressed to all that clubs that seek to participate in UEFA's European club competitions (UEFA, 2009). Each of these clubs is also subject to the financial threshold of de minimis (Müller et al., 2012). UEFA's executive committee, which is comprised of the European Football Associations' Union as well as the governing body of European football, established these regulations in September 2009 (Storm, 2012). Their aim is to increase competition in European football and to prevent football clubs from failing. UEFA's rules essentially seek to safeguard professional football's future wellbeing and growth by preventing clubs from spending more than they earn in an effort to improve their financial management and performance. In particular, the first provision of Article 57 identifies the subjects that must respect these rules as follows: "all licensees that have qualified for a UEFA club competition must comply with the monitoring requirements". Nevertheless, there are some exceptions, as "a licensee that demonstrates it has relevant income and relevant expenses (as defined in Article 58) below EUR 5 million in respect of each of the two reporting periods ending in the two years before commencement of the UEFA club competitions is exempt from the break-even requirement".

Corroborating the financial football dimensions and specific accounting regulations in the field, the current paper aims to highlight exploratory research on players' registrations. These registrations are 
included explicitly as an intangible asset in the professional football companies' financial reports. Given their high value, they are now considered an important determinant of corporate value (Oliveira et al., 2010; Lev, 2001).

Because players' registrations comprise a substantial part of major football clubs' total assets, this study intends to critically analyse the information of the impairment test. Furthermore, it reveals what types of information clubs disclose on their financial reports, as well as how they choose to disclose it, in order to discover how the enrolment and valuation of players' registrations can be treated appropriately (Gazzola and Amelio, 2015). In line with Risaliti and Verona (2012), the research acknowledges that financial reporting and accounting provide a pertinent basis for the overall analysis, standing for a "stimulus to determine certain corporate conduct" (p. 39). They place the investigation beyond the scope of Italian clubs, which have been the object of reference historically. As a result, they substantively investigate the nature and the larger scale of the present practices, which are supported by the scarcity of previous context-specific studies. Considering this fact, a further and thorough analysis is necessary.

The prominent motive that substantially differentiates this study from the previous ones, besides the sample under investigation, is the analysis of the potential correlations between the IAS/IFRS standards and the UEFA/FFP regulations regarding the accounting treatment of players' registration rights. Furthermore, we are motivated on an accounting-focused analysis of players' multiannual rights. As a result, we are overcoming our previous exclusive contributions on sustainability (Gazzola et al., 2017) and human capital (Gazzola and Amelio, 2015). Our current research also elaborates on previous topical publications, which are focusing on the clubs' accounting analysis (Gazzola and Amelio, 2016). More specifically, our previous Italian-limited sample studies are analysing the break-even point, as well as simple information on the impairment test. In addition, they are overlooking the relation with UEFA, concentrating only on reaching FFP (Gazzola and Amelio, 2016). Finally, André et al. (2018) are analysing IAS 36 and 38 standards. They are highlighting the value relevance and the analysts' forecasts accuracy, ignoring the peculiarities of the football sector and consequently the players' multiannual performance rights (André et al., 2018).

We organise this study into two main sections. The first section focuses on the analysis of the rules established by IAS/IFRS and the regulations introduced by UEFA in the field of FFP regulations. The second section consists of the conceptual background and the formulation of points of analysis, thus advancing a general framework for the study. The third section engages to an empirical approach, by considering the companies listed on the STOXX Europe Football Index from several European countries, from 2012 to 2016. In line with the statements available on the STOXX website (www.stoxx.com/index-details?symbol=FCTL), the index "covers all football clubs that are listed on a stock exchange in Europe or Eastern Europe, Turkey or the EU-Enlarged region". In particular, these listed clubs should be compatible with the EU Regulation 2002/1606 and adopt the IAS/IFRS regulations in their financial documents, including IAS 38 and 36 standards. The triptych of the selection criteria includes the clubs which: i) belong to the STOXX, ii) are listed on a regulated market and adopt the IAS/IFRS principles in full (the national legislator has margins of discretion in this regard), and iii) exceed the limit referred to in Article 57 of the FFP regulations.

Finally, we assume that the selected football clubs: A1) comply with the provision of IAS 36; A2) perform the impairment test; and A3) justify the reasons for their assets' devaluation. These criteria and points of analysis form the selected sample and research framework of our analysis regarding IAS/IFRS and FFP regulations.

\section{Literature review}

\subsection{Accounting for football players}

IAS/IFRS: intangible assets and multiannual rights

According to Fiori (2003), multiannual rights to exploit the footballers' performance are "the tie between the athlete and the club, which may be construed as an atypical intangible asset. A sort of asset that gives the rights to exploit the performance for a set amount of time and that is sold by one club to another, in case the footballer is transferred". Current literature, considers them as "assets" (Gelmini, 2014) and in particular "intangible assets" (Mancin, 2009; Amir and Livne, 2005; Vernhet and Augé, 2010).

A correct interpretation of the players' registration rights data, as recorded in the financial statements of the clubs surveyed, recalls the multilevel rules that underlie the accounting standards of such 
assets. To overcome the comparability problems of European firms' financial statements, EU has launched over the years a harmonization and standardization process (Rossi, 2007). Therefore, EU follows both stages of the convergence process. Firstly, it initiates a harmonization process, which aims to reduce the differences in accounting practices, by issuing two important directives (Abate et al., 2008, Dezzani, 2006).

Recently, following the Lisbon European Council of 24th March 2000, the stage of standardization was initiated to further adopt appropriate acts to improve the comparability of listed companies' financial statements. Towards this end, the International Accounting Standards Board (IASB) developed IAS/IFRS international accounting standards. In particular, the introduction was realised in 2002 with the Regulation (EC) No. 1606/2002. Regulation (EC) No. 1725/2003 came next and a number of other related regulations (so-called "homologation") were issued to normalise the practical community application of IAS/IFRS. In particular, with the Regulation No. 1606 of 2002, the EU enforced IAS/IFRS to the consolidated financial statements of listed companies (Simga-Mugan and Hosal-Akman, 2005).

IAS 38 establishes that intangible asset is an identifiable non-monetary asset without physical substance. An asset is a resource that is controlled by its holding entity, due to past events (e.g., purchase or self-creation) from which future economic benefits (e.g., inflows of cash or other assets) are expected (IAS 38.8). Concluding, the three critical attributes of an intangible asset include:

- Identification

- Control (power to obtain benefits from the asset)

- Potential economic benefits (such as revenues or reduced future costs).

Intangible assets are initially measured at acquisition cost (IAS 38.24). Subsequently, the entity must choose either the cost model or the revaluation model for each class of intangible asset (IAS 38.72). The cost model clearly defines that after initial recognition intangible assets should be carried at cost, less accumulated amortisation and impairment losses (IAS 38.74). The revaluation model states that intangible assets may be carried at a revalued amount (based on fair value), less any subsequent amortisation and impairment losses. Although, fair value (Elfaki and Hammad, 2015) should be determined by reference to an active market (IAS 38.75). Under the revaluation model, revaluation increases as 'other comprehensive income' and accumulated in the equity 'revaluation surplus'. On the contrary, it reverses a revaluation decrease previously recognised in profit and loss. If the revalued intangible has a finite life and is, therefore, being amortised the revalued amount is amortised (IAS 38.85). The cost less residual value of an intangible asset with a finite useful life should be amortised on a systematic basis over that life cycle (IAS 38.97). An intangible asset with an indefinite useful life should not be amortised (IAS 38.107). Its useful life cycle should be reviewed each reporting period to determine whether events and circumstances continue to support an indefinite useful life assessment for that asset. If they do not, the change in the useful life assessment from indefinite to finite should be accounted as a change in an accounting estimate (IAS 38.109). The asset should also be assessed for impairment in accordance with IAS 36 (IAS 38.111).

IAS 36 (Hassine and Jilani, 2017) states that at the end of each reporting period, an entity is required to assess whether there is any indication that an asset may be impaired (e.g., its carrying amount may be higher than its recoverable amount). For intangible assets with indefinite useful lives, the impairment test must be carried out at least once a year, regardless of whether there are any impairment or value reducing indicators. For other assets included in IAS 36, instead, the firm must control, at least at the end of each administrative period, the existence of indicators indicating a probable reduction in value. If these indicators are present, an impairment test is in order.

The asset's impairment loss must then be credited among the negative components of the profit or loss for the period. In the case that we have revaluated assets, we recognise impairment loss in 'other comprehensive income'. If value reduction loss exceeds the amount of the revaluation, then a surplus must be credited among the negative components of the profit or loss for the period.

The high levels of professional football clubs' investments in intangibles assets motivate us to analyse further their key financial communication factors (Cooper and Johnston, 2012). Multiannual rights exploiting the players' performance are recognised as intangible assets (Vernhet and Bernard, 2010). According to Fort and Quirk the player registrations are the key factor in the financial communication of professional football clubs (Fort and Quirk, 2004). 
The intangible assets of their financial reports (Michie and Verma, 1999) include the expenses incurred to a football club for the rights to exploit the professional performance of a player: the player registration. The rights result to a contractual agreement between the club and the footballer (Biancone and Solazzi, 2012). Consequently, their value corresponds to an advantage for the rights' holding club, as a potential provider of future economic benefits.

Investments in player contracts by football companies have to be capitalised and amortised. On the contrary, Amir and Glad argue that there is a high degree of uncertainty associated with such contracts, and it is not clear that this treatment is consistent with asset capitalisation criteria (Amir and Livne, 2005). The acquisition cost of multi-year rights consist of a:

- Legal agreement with another club owner where historical cost of the purchased asset's price is agreed, including other fees.

- Free agent footballer. In this case, given the difficulty of defining the purchase price, the footballer is registered among the costs of this period and not between the intangible assets, until the effect of an official evaluation.

- Transfer of the player on loan. The player is registered to the intangible assets of the transferring club, while it poses as a cost for the assignee club period.

- Legal agreement with another club owner based on the historical cost to be capitalised and the amount of money paid according to the book value of the player.

Overall, only direct costs of acquiring a player's registration can be capitalised. For accounting purposes, the carrying value of an individual player must not receive a higher revaluation, even though management may believe so. It is acknowledged that a licence applicant may be able to generate some value from the use and/or transfer of locally trained players. Although, for accounting purposes, costs relating to an applicant's own youth sector must not be included in the balance sheet, as only the cost of players purchased is to be capitalised. All forms of consideration to and/or benefit of players (such as signon fees) must be treated as employee benefits expenses and not as costs of acquiring a player's registration. Finance costs arising in respect of borrowings are treated as finance costs and are not costs of acquiring a player's registration even if the borrowings were obtained to help finance the acquisition of player registrations (UEFA, 2018).

Player registrations are intangible assets with finite useful life, for this reason, at the end of each reporting period, a football club is required to assess whether there is any indication that a footballer may be impaired, as determined by UEFA (2015) and by IAS 36. According to Maglio and Rey (Maglio and Rey, 2017), UEFA (2015) evidently acts based on IAS 36 requirements. IAS 36 adheres to the obligation of an annual impairment test on multiannual rights, as follows: "if the recoverable amount for an individual player is lower than the carrying amount on the balance sheet, the carrying amount must be adjusted to the recoverable amount and the adjustment charged to the profit and loss account as an impairment cost".

Finally, from the combined provisions of IAS 36 and the UEFA 2015-2018 regulation, it is clear that despite the fact that multiannual rights are included among the assets with a definite useful life, an impairment test at least at the end of each football season, should be carried. These regulations should be considered not only because of injuries or because of unfavorable events related to the player, but also due to the failing objectives set at the beginning of the sports season. These complications demonstrate that the IAS/IFRS standards are unsuitable for the football sector and demand supplemental FFP regulations. FFP's role is to supplement, at secondary level, the hierarchy of regulatory sources. As a result, we discover that the IAS/IFRS standards are not coherent with the football sector. Football sector's financial reporting is the only sector where human resource accounting is extensively registered (Morrow, 1996; Rowbottom, 2002), especially in relation to transfer fees (Morrow, 1999).

\section{Financial Fair Play Regulations}

As previously underlined, for sustainability purposes, in 2009 UEFA introduced the so-called "Financial Fair Play regulations". According to these regulations, each club receives a UEFA club license to participate in the Champions League or Europa League. Therefore, a series of regulatory standards are synopsised in the following five criteria: (i) sporting criteria; (ii) infrastructure criteria; (iii) personnel and administrative criteria; (iv) legal criteria and (v) financial criteria (UEFA, 2018). "Nowadays over 1,500 clubs 
in Europe undergo club licensing on an annual basis and, although there is no obligation to apply the system domestically, 51 of UEFA's 54 member associations also apply some kind of club licensing and regulatory controls for the participation in domestic competitions" (UEFA, 2015b). As stated by article 2, the regulations aims are:

i. "to further promote and continuously improve the standards of all aspects of football in Europe and to give continued priority to the training and care of young players in every club;

ii. to ensure that clubs have an adequate level of management and organisation;

iii. to adapt clubs' sporting infrastructure to provide players, spectators and media representatives with suitable, well-equipped and safe facilities;

iv. to protect the integrity and smooth running of the UEFA club competitions;

v. to allow the development of benchmarking for clubs in financial, sporting, legal, personnel, administrative and infrastructure-related criteria throughout Europe".

Furthermore, the FFP regulations aim to achieve financial fair play in UEFA club competitions and in particular:

vi. "to improve the economic and financial capability of the clubs, increasing their transparency and credibility;

vii. to place the necessary importance on the protection of creditors and to ensure that clubs settle their liabilities with employees, social/tax authorities and other clubs punctually;

viii. to introduce more discipline and rationality in club football finances;

ix. to encourage clubs to operate on the basis of their own revenues;

$x$. to encourage responsible spending for the long-term benefit of football;

xi. to protect the long-term viability and sustainability of European club football".

Nevertheless, the main issue of the FFP regulation concerns the break-even point requirement, which is critical for their economic survival. As stated by Article 57 (UEFA, 2018), "All licensees that have qualified for a UEFA club competition, with the exception of the UEFA Women's Champions League, must comply with the monitoring requirements, e.g., with the break-even point requirement (Articles 58 to 64)". A monitoring period covers three consecutive reporting periods on which a licensee is assessed for the purpose of the break-even point requirement (Art. 59). "The difference between relevant income and relevant expenses is the break-even result, which must be calculated in accordance with Annex $X$ for each reporting period" (Art. 60). It is important to underline that the UEFA FFP is closely related to the impairment test, as it emerges from Annex X (UEFA, 2018), which includes among the relevant expenses to be considered for the calculation of the break-even point "Loss on disposal and amortization/impairment of player registrations (and/or costs of acquiring player registrations)".

Regardless of the requirements of IAS/IFRS or national accounting standards, these regulations require all applicants to disclose and provide the licensor with a specific minimum level of financial information so that the licensor can assess the club's financial stability and ensure the financial fair play in UEFA club competitions (UEFA, 2015). For transparency and control purposes, UEFA requires from the clubs to disclose their revenue, in different categories, in order to achieve a viable break-even point, (e.g., gate receipts, sponsorship and advertising, broadcasting rights, commercial activities, UEFA solidarity and prize money, other operating income). Failure to comply with these regulations, the CFCB (Club Financial Control Body) can adopt a series of sanctions and disciplinary measures. The most common sanctions include:

i) warning;

ii) reprimand;

iii) fine;

iv) points deduction;

v) withhold revenues from a UEFA competition;

vi) prohibition on registering new players in UEFA competitions;

vii) restriction on the number of players that a club may register for participating in UEFA competitions;

viii) disqualification from competitions in progress and/or exclusion from future competitions;

ix) withdrawal of a title or award. 
In relation to the IAS/IFRS - FFP regulations, annex VI "minimum disclosure requirements for the financial statements" states: "Each class of intangible asset must be disclosed separately (e.g., player registrations, goodwill, other intangible assets). The following information must be disclosed for each class of intangible asset:

i) the gross carrying amount and the accumulated amortization (aggregated with accumulated impairment losses) at the beginning and end of the period; and ii) a reconciliation of the carrying amount at the beginning and the end of the period, showing additions, disposals, decreases during the period resulting from impairment losses recognized in the profit and loss account during the period (if any) and amortization". Finally, Annex VII "Basis for the preparation of financial statements" clearly states that: "All capitalized player values must be reviewed each year by management for impairment. If the recoverable amount for an individual player is lower than the carrying amount on the balance sheet, the carrying amount must be adjusted to the recoverable amount and the adjustment charged to the profit and loss account as an impairment cost. It is recommended that each licensor requires each of its license applicants to apply consistent accounting policies in respect of player registration costs."

As a result, the FFP Regulations give clubs the opportunity to choose between the following two accounting policy options: i) either to capitalize the costs of acquiring a player's registration as an intangible asset; ii) or to expense the costs of acquiring a player's registration. This second option is possible when national and international accounting practices are in accordance. Therefore, our sample analysis clubs are unable to choose this second option, due to the submission of the regulatory level (FFP) to the higher hierarchical level (IAS/IFRS).

\subsection{Conceptual background and formulation of points of analysis \\ Research framework}

Pursuant to Oprean and Oprisor (2014), the high levels of investment in football club' intangible assets require a key factors analysis in professional football clubs' financial documentation (Cooper and Johnston, 2012). The multiannual rights of the players' performances are contained among the intangible assets (Vernhet and Bernard, 2010). Fort and Quirk (2004) state that, in the context of professional football clubs, player registrations are a key element in financial communication. Documentation of player acquisition and registration in contemporary financial statements represents a substantial piece of major European football clubs' total assets. Professional football clubs have significant intangible assets (Wyatt, 2005; Risaliti and Verona, 2012) that mainly relate to players' acquisitions and registration rights, including fees for registration and agents. Indeed, players' agents are paid agent fees by clubs when transferring or extending players' contracts. The clubs believe that the fees meet the criteria to be capitalised as intangible assets, because they directly relate to the players' contract costs.

Industry statistics (Statista, 2017) verify that the media rights value of the leading football leagues in Europe in 2016/2017 is considerable and noteworthy. The highest value concerns the English Premier League $(4,028.2$ million euros) followed by the Spanish LaLiga (1,681.2 million euros), the Italian Serie $A$ (1,148.6 million euros), the German Bundesliga (801.2 million euros) and the French Ligue 1 ( 770.5 million euros). Simultaneously, the clubs that participate in the League and Europa League championships average a value of 1,964.4 million euros (Statista, 2017). Recently, the CIES Football Observatory published their top 100 most valuable players in the world (CIES Football Observatory, 2017). The top five most valuable league players are the following: i) Neymar from FC Barcelona (ESP), with 246.8 million euros; ii) Lionel Messi, his teammate, with 170.5 million euros; iii) Paul Pogba from Manchester Utd (ENG), with155.3 million euros; iv) Antoine Griezmann from Atletico Madrid (ESP), with 150.4 million euros; and, v) Luis Suarez from FC Barcelona (ESP), with 145.2 million euros. The top five most valuable lists, is followed by a list of ten players who have an estimated value of more than 100 million euros. This list includes the top five plus Harry Kane from Tottenham (ENG), Cristiano Ronaldo from Real Madrid (ESP), Paulo Dybala from Juventus (ITA), Dele Alli from Tottenham (ENG) and Eden Hazard from Chelsea (ENG). Overall, in the top 100 list, there are 42 players from the English Premier League, 25 from the Spanish LaLiga, 16 from the Italian Serie A, 12 from the German Bundesliga and 5 from the French Ligue 1.

These values (which include all expenses that a football club claims to take advantage of a player's professional performance rights) are stunning intangible assets for football club financial statements 
(Michie and Verma, 1999). As argued by Biancone and Solazzi (2012), these rights are executed on the basis of a contractual agreement between the club and the player. Therefore, the contract value grants an exclusive advantage for the club, as the holder of the player's rights. Consequently, the player's value is assumed to last for quite some time and thus provide future economic benefits. As a result, any investment in a player's contract by a football company has to be capitalised and amortised. In addition, some authors in the literature (Forker, 2005; Amir and Livne, 2005) suggest that the lack of clarity regarding how this practice meets asset capitalisation criteria leads to significantly uncertain contracts.

Despite the divergent approaches to the matter and the inherent scepticism, football remains the only industry in which human resource accounting, specifically accounting for transfer fees, applies to financial reporting (Morrow, 1996 and 1999; Rowbottom, 2002). IAS 38 (1998) includes among intangible assets the fair value of players' transfer fees (Chee Chiu Kwok \& Sharp, 2005). As a result, the amount paid when acquiring a player must be capitalized (Amir and Livne, 2005). One important reason for acknowledging intangible assets is the potential value-relevance of such information (Wyatt, 2008). In this framework, as suggested by Vishnani and Shah (2008) value-relevance is defined as follows: "[...] it has the significantly strong predicted association with the stock price and stock market indicators".

Over the years, the Financial Fair Play Regulations has primarily concentrated on the financial position and performance of the clubs, while their financial reporting has been a secondary objective (Madden, 2012). Pursuant to Article 47, the FFP requirements must be presented in audited financial statements, or alternatively, clubs must provide them separately in accordance with previously agreed procedures (UEFA, 2012). By making the secondary procedure more expensive, the UEFA is trying to encourage clubs to transparently disclose the required information without further motivation. The UEFA (2013, p.8) recognized it in the Benchmarking 2011 report: "[...] licensing has had a huge impact in improving overall disclosure in football over the last ten years" (Morrow, 2014).

According to Cooper and Joyce (2013), financial difficulties sometimes faced by clubs lead to insolvency proceedings. In this situation, clubs must implement an approach that is more transparent, economically reasonable and sustainable (Gazzola and Amelio, 2016).

\section{Formulation of points of analysis}

According to IAS 36, entities must assess all indications of asset impairment at the end of each reporting period. In the case of indefinitely useful intangible assets, the impairment test must be carried out at least once a year. Such a practice is in order regardless of whether there are any impairment indicators or whenever there are any signs of a probable value reduction (Huikku et al., 2017). For other assets included in IAS 36, instead, the firm must ascertain, at least at the end of each administrative period, the existence of indicators pointing to a probable reduction in value. If these indicators are detected, the impairment test must be carried out. In line with the aforementioned considerations, we presume the following:

A1) Football clubs comply with the provision of IAS 36.

The asset's impairment loss must be credited between the negative components of the profit or loss for the specific period, unless these assets are subject to previous revaluations (specifically, in this case, Other Comprehensive Income includes the impairment loss). Therefore, if the loss for value reduction exceeds the amount of the revaluation, the surplus must be credited between the negative components of the profit or loss for the period.

In general, in accordance with the EU Regulation, listed companies began to apply the IAS/IFRS regulation starting in 2005 (Hoogendoorn, 2006), although the regulation pursuant to IAS 36 and 38 came into force only following the EU Regulation 1126/2008 (Sahut et al., 2011).

The choices made by the national legislators regarding the option granted by Regulation 1606/2002 (Article 5), relating to the extension of the IFRS to the financial statements other than the consolidated financial statements of the listed companies, were different.

In that respect, Solntsev and Chuchina (2017) are also discussing the enhancement of the disclosure in Russian football clubs due to the application of IAS/IFRS. Their study explores the transformation of the Russian football clubs' financial statements in accordance with international standards, which was aimed at a fair view of all operations. More specifically, while the EU Regulation requires all listed companies to 
adopt the IAS/IFRS for consolidated financial statements, for non-consolidated financial statements, Article 5 grants discretion to national legislators. Naturally, therefore, the choices regarding non-consolidated financial statements vary from country to country (EU Implementation of IFRs and the Fair Value Directive A report for the European Commission). For example, Denmark (since 2009), Greece, Italy, Czech Republic, Estonia, Lithuania, Malta, Slovakia and Slovenia extended the obligation to the non-consolidated financial statements of listed companies. Simultaneously, Denmark (until 2009), Finland, Germany, Ireland, Luxembourg, Netherlands, Portugal, United Kingdom, Norway, Iceland, Liechtenstein and Poland resorted to optional application of IAS/IFRS accounting standards for the non-consolidated financial statements of listed companies. Conversely, Austria, Belgium, France, Germany, Hungary, Slovakia, Spain and Sweden do not permit any companies to prepare their legal entity financial statements in accordance with IFRS. Companies may prepare supplementary legal entity financial statements in accordance with IFRS, but these financial statements do not meet national regulatory requirements. For this reason, the correlation between listed companies and IAS/IFRS adoption is not always verified.

Finally, even if a club adopts the IAS/IFRS and complies with the provision of IAS 36, that does not necessarily mean that it has performed the impairment test as required by IAS 36. For this reason, it is presumed that:

A2) The football clubs (that conform) perform the impairment test.

Maglio and Rey (2017) consider the significance of the impairment test in the financial reports of football teams. They reveal that the financial communications disclosed, by the football clubs they analyse (Italian, English and Scottish) are inadequate. Pavlović et al. (2014) affirm the disclosure importance in the evaluation of transfer fees because they are the second largest expenditure in the football industry, following salary costs. In addition, Regoliosi (2016) emphasise how the results of Italian football clubs depend on their ability to run "player development". Therefore, they are creating a new kind of business model that could be considered as an "alternative" one, since football clubs have underscored their role in providing entertainment through competitive sport.

From an accounting point of view, players' registration rights are intangible assets with a defined useful life. It has duration equal to that of the sports performance contracts signed with the players.

These multi-year rights are recorded in the financial statements. They are recorded at cost. They are inclusive of accessory charges and possibly discounted in the event of payment deferred over time. The cost of entry on the balance sheet is amortised on a straight-line basis, according to the duration of the contracts stipulated between the company and the individual players. The value of intangible assets with a finite life (this is the case of players' registration rights) should be subject to an impairment test when there are indicators of impairment (Gazzola and Amelio, 2016). Paragraph 9 of IAS 36, in fact, requires "[a]n entity shall assess at the end of each reporting period whether there is any indication that an asset may be impaired". If there is an indication of this type, the company must estimate the recoverable value of the asset. Then the impairment test must be carried out; that is, the recoverable value of the asset must be estimated and compared to the carrying amount.

The recoverable amount is the highest between two values, i.e., the value in use (for example, the present value of future cash flows expected to be generated by the asset) and the fair value of the asset minus sales costs (that is, the net amount obtainable in the event of sale).

Not all clubs perform the impairment test. Moreover, even if they submit the asset to this test, they do not always explain the reasons that led to the devaluation. This could lead to disclosure problems (Gazzola et al., 2017). It is in this particular point that a central issue of the study emerges. IAS 36 sets out the rules for carrying out the impairment test (in paragraph 7) and for recording the related devaluation in the financial statements (in paragraph 126). FFP regulations, in the "notes to the financial statements" section state: "Each class of intangible fixed asset must be disclosed separately (e.g. player registrations, goodwill, other intangible assets). The following information must be disclosed for each class of intangible fixed asset:

i) the value at the beginning and end of the period of: the accumulated amortization (with accumulated impairment losses) and the gross carrying amount; and 
ii) a reconciliation of the carrying amount at the beginning and the end of the period, showing additions, disposals, decreases during the period resulting from impairment losses recognised in the profit and loss account during the period (if any) and amortisation". Thus, it is presumed that:

A3) Football clubs provide transparent justification for the reasons that led to the devaluation.

Although IAS 36 does not require disclosure from this point of view, the combination IAS 36 and FFP regulations would seem to suggest this logic. Moreover, FFP regulations require the drafting of a document (F) called "player identification table" to be provided to the auditor, whose function is to "reconcile the aggregate figures in the player identification table to the relevant figures in the balance sheet and profit and loss account in the audited annual financial statements". In this way, the disclosure problem seems to be solved, but it continues the statement continues as follows: "the player identification table does not need to be disclosed within the annual financial statements".

\section{Methodology of research}

As stated previously, in order to analyse the assessment and application of the impairment test (IAS 36) to intangible assets (IAS 38) of football companies that prepare financial statements in accordance with International Financial Reporting Standards (IAS / IFRS), the study focuses on clubs listed on the STOXX Europe Football Index. The website of this index states that it "covers all football clubs that are listed on a stock exchange in Europe or Eastern Europe, Turkey or the EU-Enlarged region". In this index there are 22 teams from different European countries and, as claimed by Biancone and Solazzi (2012), "gives an accurate snapshot of the football industry in Europe". The teams are the following: Borussia Dortmund (DE), Galatasaray (TR), Juventus (IT), Parken Sport \& Entertainment (DK), Fenerbahce Sportif Hizmet (TR), Besiktas (TR), Olympique Lyonnais (FR), Trabzonspor Sportif Yatir (TR), Celtic (GB), AS Roma (IT), AFC Ajax (NL), Lazio (IT), Brondby If B (DK), Aalborg Boldspilklub (DK), Arhus Elite (DK), Sport Lisboa e Benfica (PT), Silkeborg (DK), Teteks Ad Tetovo (MK), AIK Football (SE), Sporting (PT), Futebol Clube Do Porto (PT), Ruch Chorzow (PL).

Historically, numerous market indices have been created by investment banks and specialized news agencies. The first market index to analyse the performance of football companies' titles was generated by Nomura in 1992, taking into consideration 14 clubs between English Premier League and Scottish Premier League. Later, Bloomberg responded through the preparation of what until a few years ago was considered the main reference tool for the aggregate data of the football sector on the stock exchange: the Bloomberg Kick Index. This index considers the share prices of top 20 British listed companies, by capitalization. However, the main football clubs index is the STOXX Europe Football Index, developed by the company Stoxx on 22 of April 2002 (called earlier Dow Jones Stoxx Index Football). It initially included all 33 European football clubs. Currently, the index counts 22 teams. The cost increase and the strong dependence on sports results led many clubs to a delisting, while more and more football clubs abandoned the financial markets. Thus, over the years, the number of listed companies began to decline: 30 in 2009, 25 in 2015, up to the current 24, including 22 in the STOXX Europe Football Index. Despite their stock exchange listing, two major UK teams are not part of the STOXX: Arsenal FC and Manchester United FC. The shares of Arsenal Holding PLC are listed on the Plus Markets and therefore are not considered in the STOXX. Plus Markets is a parallel circuit of the London Stock Exchange. After the abandonment of the stock market, Manchester United decided in 2012 to list itself on Wall Street (in the USA, therefore outside the STOXX area). In Europe, there are many other large teams (for example Real Madrid CF, FC Barcelona, FC Bayern München) but they are not listed on the stock market and therefore are not part of the STOXX index.

The choice of the STOXX and therefore the decision to exclude other large European teams, lies in the opportunity to access the information made public by the listed teams, in response to regulatory obligations. The process of listing on regulated markets requires the adoption of disclosure practices (Patton \& Zelenka, 1997). These practices are imposed by the various regulating and control bodies of the national stock exchange, which are only partially present for the teams that do not comply with the equities' listing. Therefore, the general concept of market disclosure links to the disclosure of player registration, which is the central theme of this research. 


\subsection{Sample: selection criteria}

In particular, firstly we consider all the STOXX listed companies' financial statements and secondly, according to three selection criteria, we analyse them over five years (from 30 June 2012 to 30 June 2016), following the UEFA's Financial Fair Play Regulations ruling in September 2009, which was subsequently implemented in 2011/2012. Although all the STOXX companies' financial statements have been analyzed (for 5 years), Turkish (Galatasaray, Fenerbahce Sportif Hizmet, Besiktas, Trabzonspor Sportif Yatir) and Polish (Ruch Chorzow) teams are excluded from the sample population due to non-integral application of IAS/IFRS principles. Turkish teams prepare financial statements in accordance with Turkish Accounting Standards (TAS) promulgated by the Public Oversight Accounting and Auditing Standards Authority (POA) that are set out in the communique numbered 11-14,1 "Communique on the Principles of Financial Reporting in Capital Markets" (the Communiqué) announced by the Capital Markets Board ("CMB"), which is published in Official Gazelle numbered 28676. According to the "notes to the financial statements section", the financial statements have not quantified the impact of variances between the Financial Reporting Standards, which are published by the Capital Market Board in Turkey, the accounting principles generally accepted in countries where the financial statements are to be distributed, and International Financial Reporting Standards (IFRS). For this reason, it is not the goal of the financial statements to present the financial performance and position of the Turkish clubs according to the principles of accounting generally accepted in such countries and by the IFRS. Similarly, the Polish team's financial statements are prepared according to an accounting law from 29 September 1994.

In addition, the sample also excludes four other small-sized companies that do not meet the requirements of the remaining 13 companies (Brondby If B, Arhus Elite, Teteks Ad Tetovo and AIK Football). The reason lies in the provision of Article 57 (FFP regulations). This article clearly states that "all licensees that have qualified for a UEFA club competition must comply with the monitoring requirements". "A licensee that demonstrates relevant income and relevant expenses (as defined in Article 58) below EUR 5 million in respect of each of the two reporting periods, ending in the two years before commencement of the UEFA club competitions, is exempt from the break-even requirement".

The study focuses only on STOXX European clubs that adopt IAS/IFRS regulations. Not all the UEFA listed companies are obliged to adopt IAS/IFRS rules. Indeed, as the FFP regulations refer: "financial statements as defined in Articles 47 and 48 must be based on the accounting standards required by the local legislation for incorporated companies - either the applicable financial reporting framework of the relevant country, the International Financial Reporting Standards or the International Financial Reporting Standard for Small and Medium-sized Entities". Therefore, it is not automatic that all clubs that follow FFP must follow IAS.

Building on the aforementioned arguments, the following selection criteria comprise our sample:

- The clubs belong to the STOXX: 22 teams;

- The clubs are listed on a regulated market and adopt the IAS/IFRS principles in full (the national legislator has margins of discretion in this regard): 17 teams;

- The clubs that exceed the limit are referred to Article 57 of the FFP regulations: 13 teams.

\subsection{Method and procedure}

Settling the focus of this paper on some variables of interest and the relationships among them, it aims to analyse the surveyed clubs' financials as a pertinent endeavour within the overall framework of the study (Van Beest et al., 2009; Bloomfield et al., 2015). The decision to analyse financial statements is supported by several reasons. Firstly, because items can be examined and measured as they are, taking into account the official reports released by the companies themselves (Morrow, 2013). Secondly, because financial statements comprise key figures and display meaningful relationships among them, resulting in "invaluable document/performance reports" (Ganga et al., 2015). Thirdly, because financial statements are deemed as "the main source of information for a wide range of users", despite the risk of variables' subjectivity, "subject to manipulations ("creative accounting")" (Risaliti and Verona, 2012). Given the ability of financial statements to provide a fair outlook of a company's financial condition, although all the financial statements of listed companies have been analysed for 5 years, the research addresses 65 financial statements according to the following three-step procedure: 
i) selection of the companies surveyed, 13 teams in total;

ii) screening of the documents (to be analysed): 65 financial statements from 2012 to 2016 drawn up according to IAS/IFRS;

iii) choice of important facts and figures to aid in point of analysis testing.

As a preliminary endeavour, we selected to examine financial statements based on which football clubs have adopted the IAS/IFRS principles to prepare their financial statements. Next, we analyse the financial statements that were published from 2012 to 2016. Finally, we develop empirical descriptions of the existing data by scrutinizing the figures extrapolated from the teams' financial statements with a view to selecting the relevant data for points of analysis testing. Here, the frame of reference of the overall analysis relies on examining adoption of the impairment test in relation to the financial statements. We emphasize operational data relating to financial year profit/loss, total assets, multi-year rights to professional footballers' performance, devaluation of those rights, and their inherent trends.

\section{Players' registration rights in the financial statements of the clubs selected}

Table 1 documents the value of the items related to multi-year rights, documented as intangible assets in the balance sheets of the 13 football clubs in the five considered years, corroborating the combined application of IAS 36 and IAS 38. All values are expressed in euros (euro '000). Therefore, the values expressed in Danish krone and in British pound are converted into euros based on an average exchange rate. The rate is calculated based on the evolution of the exchange rate over the considered years (For the Danish krone, the average exchange rate is $7.45 \mathrm{kr}$, while for the British pound, it is $0.8 \mathrm{f}$.). The study complies with the provisions of the FFP regulations, which state, "If a licensee's financial statements are denominated in a currency other than euros, then the break-even result must be converted into euros at the average exchange rate of the reporting period" (Article 60).

Table 1. Multi-year rights to exploit professional footballers' performance

\begin{tabular}{|c|c|c|c|c|c|c|}
\hline & & 2012 & 2013 & 2014 & 2015 & 2016 \\
\hline 1 & Borussia Dortmund & 25,655 & 28,350 & 61,485 & 96,082 & 64,532 \\
\hline 2 & Juventus & 118,095 & 119,222 & 119,899 & 114,235 & 186,169 \\
\hline 3 & Parken Sport \& Entertainment & 11,691 & 8,690 & 17,109 & 17,119 & 19,713 \\
\hline 4 & Olympique Lyonnais & 62,397 & 30,443 & 13,570 & 8,362 & 31,692 \\
\hline 5 & Celtic & 9,166 & 12,248 & 8,996 & 10,445 & 12,248 \\
\hline 6 & AS Roma & 82,934 & 78,748 & 89,156 & 134,709 & 192,592 \\
\hline 7 & AFC Ajax & 19,288 & 16,704 & 22,362 & 42,311 & 47,201 \\
\hline 8 & Lazio & 47,078 & 30,923 & 35,937 & 37,612 & 49,565 \\
\hline 9 & Aalborg Boldspilklub & 428 & 328 & 358 & 425 & 922 \\
\hline 10 & Sport Lisboa e Benfica & 92,065 & 97,140 & 93,565 & 88,716 & 115,192 \\
\hline 11 & Silkeborg & 246 & 196 & 104 & 17 & 74 \\
\hline 12 & Sporting & 40,219 & 28,242 & 24,726 & 19,314 & 32,070 \\
\hline 13 & Futebol Clube Do Porto & 99,255 & 76,159 & 61,506 & 65,910 & 90,625 \\
\hline
\end{tabular}

Over the analysed duration, the values trend differs depending on the club analysed. In order to better illustrate the difference, the results are shown in Figure 1.

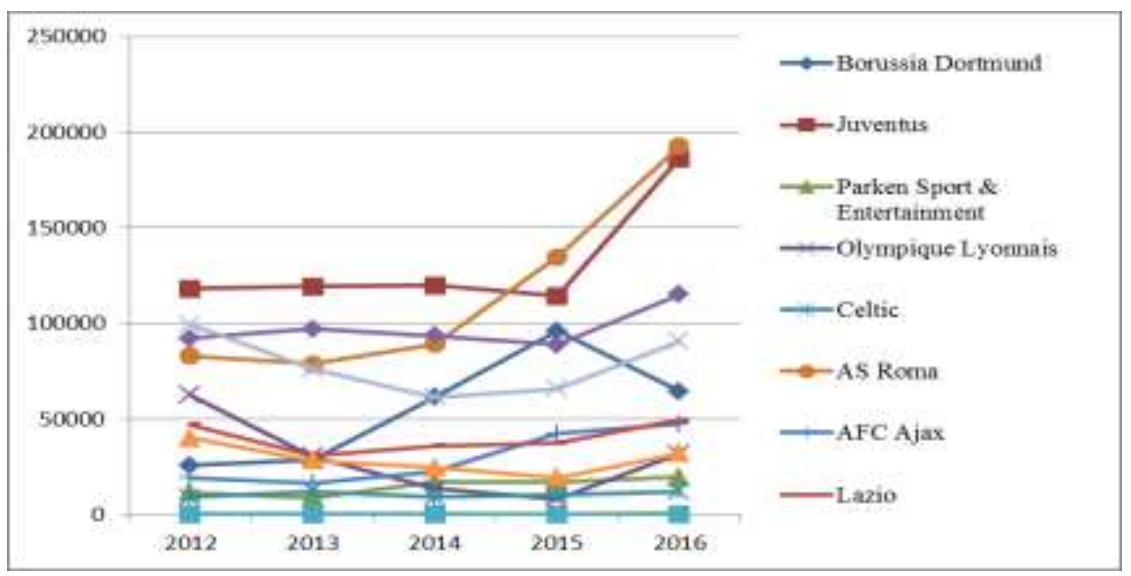


Figure 1. Multi-year rights trends

Clubs included in the sample have experienced a growing trend over the years. In the last two years alone, all clubs (except Borussia Dortmund) have shown an increase in the value of rights. Growth is more pronounced $(>, 000,000 €)$ in clubs such as Juventus, Olympique Lyonnais, As Roma, Lazio, Sport Liboa e Benfica, Sporting and Futebol Clube Do Porto (7 of 13). This growing trend has accentuated the importance of players' value and evaluation in terms of accounting and ethics, making the analysis conducted in the present study feasible and indispensable. To support the overall framework of the analysis, three other values are important: i) total assets; ii) profit/loss; and iii) the devaluation of multiannual rights. In particular, Table 2 details the first value (i) of total assets; Table 3 details the second value (ii) of profit/loss; and Table 4 details the third and last value (iii) of the devaluation of multiannual rights.

Table 2. Total assets

\begin{tabular}{rlllccl}
\hline & $\mathbf{2 0 1 2}$ & $\mathbf{2 0 1 3}$ & $\mathbf{2 0 1 4}$ & $\mathbf{2 0 1 5}$ & $\mathbf{2 0 1 6}$ \\
\hline 1 & Borussia Dortmund & 248,706 & 302,415 & 292,295 & 386,539 & 424,545 \\
2 & Juventus & 427,780 & 443,366 & 495,921 & 474,268 & 577,558 \\
3 & Parken Sport \& Entertainment & 356,912 & 363,984 & 361,921 & 372,124 & 372100 \\
4 & Olympique Lyonnais & 202,248 & 215,475 & 309,478 & 467,481 & 604,397 \\
5 & Celtic & 95,155 & 102,838 & 120,605 & 115,520 & 120,076 \\
6 & AS Roma & 303,771 & 290,031 & 332,019 & 382,978 & 442,630 \\
7 & AFC Ajax & 103,480 & 118,248 & 131,990 & 178,537 & 170,513 \\
8 & Lazio & 263,697 & 232,546 & 240,892 & 245,683 & 237,286 \\
9 & Aalborg Boldspilklub & 10,157 & 6,359 & 16,617 & 16,187 & 16,598 \\
10 & Sport Lisboa e Benfica & 411,921 & 416,671 & 440,679 & 430,210 & 476,378 \\
11 & Silkeborg & 70,242 & 68,959 & 68,748 & 68,214 & 75,568 \\
12 & Sporting & 144,408 & 139,464 & 146,752 & 235,542 & 224,339 \\
13 & Futebol Clube Do Porto & 210,727 & 227,853 & 200,396 & 359,235 & 375,045 \\
\hline
\end{tabular}

The "Conceptual Framework" provides the definition of asset [F 4.4(a)]: it "is a resource controlled by the entity as a result of past events and from which future economic benefits are expected to flow to the entity". In addition, it states that an asset [F 4.44] "is recognised in the balance sheet when it is probable that the future economic benefits will flow to the entity and the asset has a cost or value that can be measured reliably". In relation to the financial position statement, IAS 1 requires a minimum mandatory content. Specifically, according to IAS 1.54, the following items must be included: property, plant and equipment; investment property; intangible assets; financial assets (excluding amounts shown under (e), (h), and (i)); investments accounted for using the equity method; biological assets; inventories; trade and other receivables; cash and cash equivalents; assets held for sale; trade and other payables; provisions; financial liabilities (excluding amounts shown under ( $(\mathrm{k})$ and $(\mathrm{I})$ ); current tax liabilities and current tax assets, as defined in IAS 12; deferred tax liabilities and deferred tax assets, as defined in IAS 12; liabilities included in disposal groups; non-controlling interests, presented within equity; and, issued capital and reserves attributable to owners of the pare.

Multiannual rights represent intangible assets. IAS 38.8 defines an intangible asset as an "an identifiable non-monetary asset without physical substance". It is a resource that a company controls as a result of past events (for example, purchase) and from which it is expected to obtain future economic benefits (cash inflows). Consequently, the three elements that characterize an intangible asset are: i) identifiability; ii) control; and iii) future economic benefits. Multiannual rights fall within this definition. Therefore, they can be considered intangible assets. For a better representation, Figure 2 illustrates the total assets trends of the selected football teams.

We are observing Borussia Dortmund, Juventus, Olympique Lyonnais, As Roma, Sport Liboa e Benfica, Sporting and Futebol Clube Do Porto have an upward trend ( 7 of 13), and 6 of these 7 are the same clubs that have a growing trend in the value of rights (and so in the companies' size). Parken Sport \& Entertainment, Celtic, AFC Ajax, Lazio, Aalborg Boldspilklub and Silkeborg also reveal a growing trend, though not as linear as the other cases.

The two dimensions considered until now (multiannual rights and total assets) are, therefore, closely related, although, the total assets value includes other important items that affect the total. 
In relation to this aspect, the situation differs from team to team. Considering an average value for the five years analysed, the incidence of multiannual rights on total assets is $>15 \%$ for some (8) teams (Borussia Dortmund, Juventus, As Roma, AFC Ajax, Lazio, Sport Liboa e Benfica, Sporting and Futebol Clube Do Porto), while it is limited for the remaining 5.

Since they refer to each financial year, Table 3 highlights the results of the income statement.

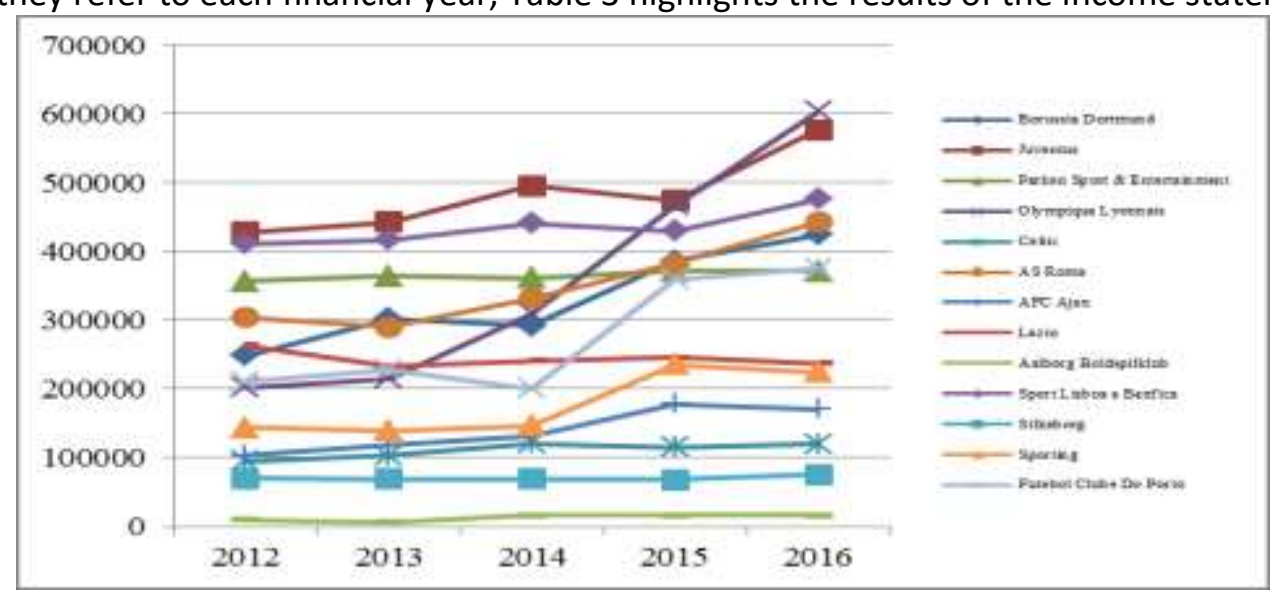

Figure 2. Total assets trends

Table 3. Profit/loss for the financial year

\begin{tabular}{|c|c|c|c|c|c|c|}
\hline & & 2012 & 2013 & 2014 & 2015 & 2016 \\
\hline 1 & Borussia Dortmund & 27530 & 51193 & 11970 & 5532 & 29436 \\
\hline 2 & Juventus & $-48,655$ & $-15,911$ & $-6,674$ & 2,298 & 4,062 \\
\hline 3 & Parken Sport \& Entertainment & 5545 & 23397 & 902 & -4620 & 8930 \\
\hline 4 & Olympique Lyonnais & -27937 & -19845 & -26440 & -21498 & 9753 \\
\hline 5 & Celtic & -9214 & 12174 & 13963 & -4934 & 574 \\
\hline 6 & AS Roma & -58268 & -43009 & -38123 & -38770 & -10433 \\
\hline 7 & AFC Ajax & 10459 & 17713 & 16422 & 21948 & -497 \\
\hline 8 & Lazio & 580 & -5395 & 219 & 293 & 976 \\
\hline 9 & Aalborg Boldspilklub & -1930 & -3633 & 5514 & 73 & 948 \\
\hline 10 & Sport Lisboa e Benfica & -11690 & -10394 & 14165 & 7072 & 20396 \\
\hline & Silkeborg & -864 & 21 & -1006 & 1226 & 492 \\
\hline 12 & Sporting & -45947 & -43816 & 368 & 19333 & -31905 \\
\hline 13 & Futebol Clube Do Porto & -35925 & 20330 & -40708 & 19958 & -58284 \\
\hline
\end{tabular}

Table 3 highlights how the results of the profit and loss account have changed over time. This table is of prominent importance if analysed in relation to the FFP regulations' prescription. It clearly underlines an on-going economic trend that alternates year after year. Therefore, it is not possible to identify a generally valid economic or financial tendency for all the companies analysed. By focusing on how value has evolved over the years, starting from the implementation of the UEFA Financial Fair Play Regulations, we can discover whether or not the situation has improved. Specifically, it is worth noting whether or not football clubs have met the break-even point at which clubs must balance spending with revenues. For a more complete picture, Figure 3 displays the main trends in this respect. 


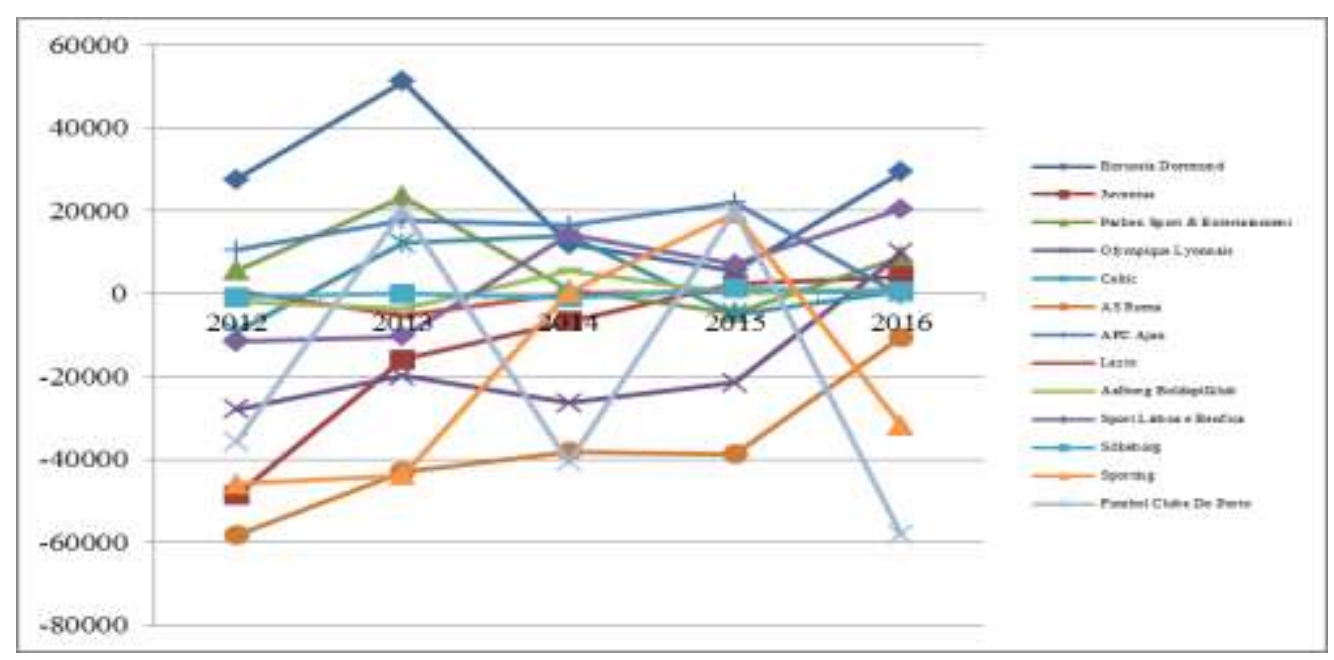

Figure 3. Performance over time of Profits/losses

Of the 13 clubs under examination, only Borussia Dortmund posted profits for every single year of the examined period. Parken Sports, AFC Ajax and Lazio were breaking even for every financial year except one (e.g., Parken Sports 2015, AFC Ajax 2015/2016, Lazio 2012/2013). After a period of negative results, Juventus reached the breakeven point for the first time in the financial year 1 July 2014 - 30 June 2015. Olympique Lyonnais reached the break-even point one year later. Aalborg and Sport Lisboa went from negative results to positive results in the 1 July 2013-30 June 2014 financial year. The results of Roma club have yet to improve; regardless of an improving trend, the break-even point remains distant. As highlighted in Figure 4, the remaining companies had alternating positive and negative results over the examined years.

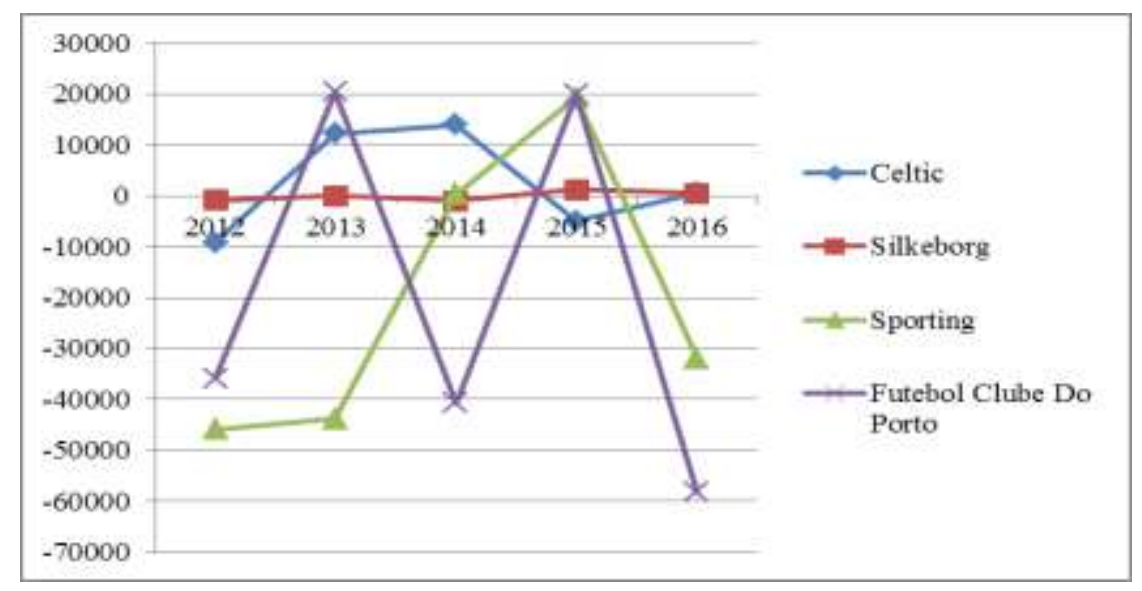

Figure 4. Profit/loss trends (4 clubs)

According to Article 61 (FFP), "the acceptable deviation is EUR 5 million. However, it can exceed this level up to EUR 30 million if such excess is entirely covered by contributions from equity participants and/or related parties. A lower amount may be decided in due course by the UEFA Executive Committee". This prevents the formation of unsustainable debt.

If a club breaches the rules, the Club's Financial Supervisory Body (FSB) imposes several penalties and restrictions. A rule violation does not result in the automatic exclusion of a club. Depending on various factors (e.g., the balanced budget trend), a club incurs various penalties. The most prominent penalties are the following: i) warning; ii) recall; iii) fine; iv) deduction of points; v) withholding of revenues generated by a UEFA competition; vi) no registration of new players for UEFA competitions; vii) limitation of the number of players a club can register for UEFA competitions, including a financial limit on the aggregate total cost of benefits for players registered on the A list of UEFA club competitions; viii) disqualification from competitions in progress and/or exclusion from future competitions; and ix) revocation of a prize. 
Moreover, the FSB has decided in many cases that the objectives of the FFP could be better achieved with a rehabilitative rather than a punitive approach. This led to several agreements between clubs and the FSB, which combine financial penalties with other punitive restrictions.

\begin{tabular}{cllllll} 
Table 4. Devaluation of multiannual & rights & (Impairment losses for the yeary \\
\cline { 2 - 7 } & & 2012 & 2013 & 2014 & 2015 & 2016 \\
\hline 1 & Borussia Dortmund & 0 & 0 & 569 & 0 & 0 \\
2 & Juventus & 5,385 & 3,226 & 63 & 4,350 & 644 \\
3 & Parken Sport \& Entertainment & 0 & 1,215 & 0 & 0 & 0 \\
4 & Olympique Lyonnais & 897 & 1,378 & 0 & 0 & 429 \\
5 & Celtic & 376 & 626 & 5,111 & 473 & 1,618 \\
6 & AS Roma & 3,622 & 464 & 2,148 & 1,218 & 676 \\
7 & AFC Ajax & 3,750 & 0 & 0 & 0 & 0 \\
8 & Lazio & 53 & 1,187 & 7 & 94 & 408 \\
9 & Aalborg Boldspilklub & 0 & 0 & 0 & 0 & 0 \\
10 & Sport Lisboa e Benfica & 4,646 & 5,163 & 550 & 0 & 597 \\
11 & Silkeborg & 0 & 0 & 0 & 0 & 0 \\
12 & Sporting & 4,551 & 5,957 & 0 & 3,483 & 1,175 \\
13 & Futebol Clube Do Porto & 3,988 & 301 & 563 & 1,147 & 1,971 \\
\hline
\end{tabular}

To understand how the impairment test (IAS 36) was adopted it is essential to understand the meaning of the item "Devaluation of multiannual rights". This value is the result of the performance of the impairment test every year, as required by the account multiannual rights. Table 4 below further explains the devaluation of multiannual rights. If the devaluation is not written in the financial statement, Table 4 shows a zero (0) value. This value expresses the "impairment loss". Therefore, due to the impairment test, that devaluation represents a loss. An example would be a negative income component that adds to other costs of the income statement and participates in the formation of the economic result for the year (profit or loss). Since it represents a cost, it should be indicated with a minus sign. For simplicity, this value is indicated in Table 4 without a sign; that is, in absolute value.

Figure 5 graphically highlights the same results in an effort to provide a clear understanding of the trends relating to the above figures.

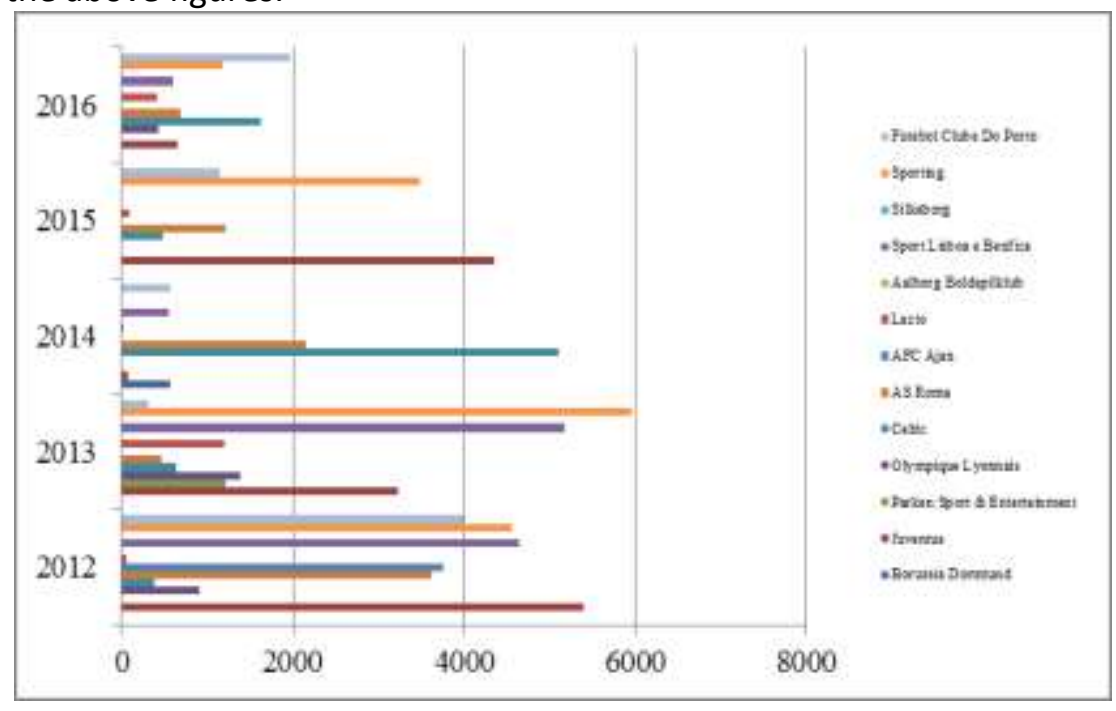

Figure 5. Devaluation of multiannual rights over time

A statement of comprehensive income is a document including profits and losses and also other comprehensive income for the financial year. The following football clubs have registered a devaluation of multiannual rights in their profit/loss accounts following their execution of the impairment test: i) Juventus; ii) As Roma; iii) Lazio; iv) Celtic; and, v) Futebol Clube Do Porto. In particular, based on the previous list, it seems that the Italian clubs have a high level of disclosure due to FIGC ("Federazione Italiana Giuoco Calcio"; i.e., the Italian Football Association), which obliges them to prepare a "prospect of multiannual rights movements" and attach it to their financial statements. Thus, this Italian directive seems to guide the 
national clubs in the right direction toward the establishment of transparent and potentially sustainable reporting practices. Considering the specific situation of other individual clubs, we note the following:

i) Borussia Dortmund specifies the value of the devaluation in the notes. Thus, in every year except 2013/2014 ("impairment losses of EUR 549 thousand were recognised in the current financial year" without other indications), there are "no indications of impairment losses". The company evaluates and amortises player registrations at cost. Their intangible assets useful lives are all finite. They are also tested for impairment if there are specific indications relating to individual assets (e.g., Notes to the consolidated financial statements, Accounting policies, pp. 145-146 - 2015/2016). This means that, in accordance with the IAS / IFRS regulations on assets with a defined useful life, this club carries out the impairment test only in the presence of specific indications (and not annually as the UEFA regulation provides), unlike the provisions for financial assets. Financial assets provisions state that "at the end of every reporting period, it is assessed whether there is any objective evidence, [...], that a financial asset [...] is impaired" (Notes to the consolidated financial statements, Accounting policies, p. 147 - 2015/2016).

ii) Juventus also evaluates and amortises player registrations at cost. In case of indicators of rights' loss of value, the devaluation of the residual load value is carried out and calculated (e.g., Notes, Significant accounting policies, pp. 69-70 - 2015/2016). As an example we could refer to injuries of particular relevance or significant capital losses deriving from sales carried out after the balance sheet date. Another example could be the market and contractual conditions that effectively prevent the disposal of players who are no longer compatible with the technical project. As a result, in relation to the 2011-2012 financial statements, Juventus made impairment devaluations because: "A portion of these devaluation ( $€ 3.8$ million) was accumulated in order to align the residual value of players' registration rights (in particular Elia and Krasic) with the net charges actually received for their [...]. A further devaluation ( $€ 1.6$ million) was accumulated to zero the net book value of the registration rights of a player expiring on June 30, 2013, and consequently released from January 2013, not included in the technical project". In addition, Juventus carried out the impairment test in the presence of indicators. Thanks to the transparency of this club, it is possible to identify the real market value of the players subject to devaluation, also available on the specialised website "market values" (https://www.transfermarkt.com/). Questioning the program it is possible to observe how the market value of the players Elia and Krasic is decreasing over the years considered. In particular, from a value of $€ 20$ million in June 2011, Krasic fell to a value of $€ 16$ million in January 2012 and finally to $€ 11$ million in June 2012. The same situation for Elia, whose value fell from $€ 8$ million (January 2012) to 5 million (June 2012). These values, which are present in the Juventus financial statement, are demonstrating high level of transparency.

iii) Parken Sport \& Entertainment exhibits a disclosure issue. In the accounting policies adopted, there is not an official IAS/IFRS cost criterion adoption declaration, although it could be assumed. In effect, from the notes' reading, the application of the cost criterion and, subsequently, the impairment test realisation can be traced clearly ("Årets nedskrivninger", Note 14, p. 37 - 2013). The method of devaluation or the timing of the impairment test is unclear. The only reference is the following: "Based on an individual assessment taking into account rental, damage and sporting presentations, contractual rights were written down in 2013 by DKK 9.1 million."

iv) Olympique Lyonnais' player registrations meet the definition criterion of an intangible asset. They are capitalised at their acquisition cost. Player registrations are also amortised at cost. Assets with a finite lifetime, such as player registrations, are tested for impairment at any time when their value may be impaired (e.g., Notes to the consolidated financial statements, Summary of significant accounting policies, note 5.3 pp. 115-116 - 2015/2016). This club is transparent from the impairment test point of view. In the notes, club states "Impairment tests are performed using the following methods:

- For player registrations held with the intent to sell, the estimated or known sale price, net of selling fees, is compared to the contract's carrying value, and a write down may be recognised where necessary;

- If an event occurs that could have an impact on the useful life of the contract (e.g., early termination of the contract by the player, irreversible disability, etc.), it may be amortised ahead of schedule

- Indications of an impairment loss are determined on two levels: 
- At the team level, an overall assessment of value in use is made by comparing the Club's discounted cash flows to the cumulative carrying value of all player registrations.

- At the individual player level, potential impairment loss is evaluated using various criteria including the player's appearance on match sheets.

The cash flows used for these tests on players are consistent with those used to calculate deferred tax assets (see Note 10.2). Management has created several scenarios, taking into account the assumptions that: i) the Club will participate in European competitions; ii) it will rank near the top of the Ligue 1 table; and iii) that the sales strategy of player registration will continue. None of the above scenarios are expected to rise to an impairment loss."

v) Celtic's costs are directly attributable to the acquisition and retention of football personnel. It capitalises them and treats them as intangible asset (e.g., Notes to the financial statements, Accounting policies, p. 36 - 2015/2016). The Group and Company impairment tests are taking place at each balance sheet date and takes in to account the following parameters:

i) Managerial intentions for the coming football season;

ii) The evidence of this intention;

iii) The level of interest from other clubs in paying a transfer fee for the player;

iv) Market knowledge of transfer appetite, through discussion with agents and other clubs;

(v) The financial state of the football industry;

(vi) The level of appetite from Scottish football clubs;

(vii) Levels of 'cover' for each player's position;

(viii) The football personnel's own career plans and personal intentions for the future;

(ix) Contract terminations."

vi) AS Roma evaluates intangible assets (registration rights) from the initiation of the contract's date. The company evaluates and amortises player registrations at cost. If impairment losses are indicated (e.g., injuries), an assessment is made to determine the recoverable amount (e.g., Explanatory notes, Accounting policies and accounting principles, pp. 144-145 - 2015/2016). "In the presence of loss of value indicators relating to players' registration rights (e.g., accidents or illness of particular relevance) and of the other intangible assets, an assessment is made to ascertain the recoverable value."

vii) AFC Ajax's player rights are measured at cost less accumulated amortisation and impairment losses (Notes, Valuation principles, p. 47 - 2015/2016). Like Celtic, this club also performs the impairment test every year "As of the balance sheet date, the Executive Board assesses per unit of cash-generating unit whether there is a lasting impairment. A cash-generating unit consists of a player group."

viii) Lazio records performance rights of professional footballers at a discounted acquisition cost, according to the market rate. It includes any additional charges if they are directly attributable. The rights are amortised over the contract's term. If a possible impairment is indicated, in accordance with IAS 36 (e.g., Notes to the financial statements, accounting policies, pp. 39-40 - 2015/2016), finitely useful intangible assets are amortised over the course of their life and remain subject to the impairment test. It is unclear whether the impairment test is performed annually or in accordance of the particular indicators of impairment, which are present.

ix) Aalborg Boldspliklub evaluates contract rights at cost minus accumulated amortisation and depreciation. Contractual rights are amortised over the contract period, which is typically 2-4 years. Depreciation and impairment losses are recognised in the result of transfer activities (e.g., Notes, Accounting policies, pp. 37 - 2015/2016). It is difficult to detect whether the impairment test is performed annually or in accordance of the particular indicators of impairment, which are present.

x) Sport Lisboa e Benfica's intangible assets are valued at their acquisition cost plus expenses directly attributable to their acquisition. Then, they are deducted from accumulated amortisation and accumulated impairment losses, if this occurs. The company annually evaluates impairment signals by analysing the specific situation of the athletes, considering qualitative and quantitative indicators. These indicators include sports performance, evolution prospects, possible contacts for a possible transfer, remaining duration of the contract, age, salary, use and injuries (e.g., Notes to the consolidated and individual financial statements, accounting policies, pp. 98-99 - 2015/2016). This club, in addition to Ajax and Celtic, conducts an annual test. 
xi) Silkeborg recognizes contractual rights as intangible assets. These are valued using the cost criterion (including direct acquisition costs) less impairment and accumulated depreciation. Contract rights are then amortised over the contract periods, and the amortisation is recognised in the income statement under "Income from transfer activities" (for example, significant accounting policies, Notes, p. 412015/2016). "The parent company fails to disclose individual contracts, including the book value and the residual amortization period". Therefore, there is no information on the impairment test and its frequency.

xii) Sporting evaluates player rights at cost less depreciation and impairment losses. Impairment of intangible assets is analysed when there are facts or circumstances indicating that their net value is not recoverable. The club periodically reviews the valuation of its rights in order to validate the existence of impairment losses. The process of analysing a possible impairment of athletes' rights is subject to estimates and judgments involving a set of variables that include the temporary transfer of the athlete to other clubs, age, non-continuous use of games, injury and punishment (e.g., Notes to the financial statements, summary of main accounting policies, pp. $115-117$ and 128-2015/2016). This club carries out the impairment test in the presence of particular indicators, unlike other intangible assets for which a test is carried out annually.

xiii) Futebol Clube Do Porto recognizes the 'Intangible assets - Players' registrations"' by including costs related with the acquisition of players' registrations. Therefore, if a loss on the recoverable amount of a player's registration ("impairment loss") is estimated, then the corresponding impact is recognised in the income statement under the caption "Amortisation and impairment losses of players' registrations'". Costs included in the caption "Intangible assets-Players' registrations"' are amortised over the period covered by contracts between the players and the company (e.g., Notes to the consolidated financial statements, Main accounting policies, p. 41 - 2015/2016). In particular, it seems that the test is carried out only in the presence of particular indicators, as indeed specified in Note 8. "For the fiscal year ending June 30, 2016 impairment losses amounting 1,971,283 Euro were recorded. These losses are related with the registration of the Helton players, as FCP and SAD, terminated their contracts for the season 2016/17. For Ghilas there were no registered losses, as he was loaned during the season 2016/2017, (note 2.3.b). For the previous year, ended June 30, 2015 impairment losses amounting 1,146,645 Euro were recorded. The losses were related with the registration of the players Djalma, Opare and Quinones, as FCP and SAD terminated their contract with these players during the season 2015/16" (https://www.transfermarkt.com/).

According to IAS 36 par. 12, impairment tests consider information available from both internal and external sources. FFP regulations (UEFA 2018), foresee particular internal hypotheses of devaluation of the multi-year rights (leaving out, however, the external indicators). In particular, Annex VII states that: "a player will not be able to play again with the club, if he suffers a career-threatening injury or he is permanently unable to play professional football". In such a case, the net book value of the player's registration on the balance sheet must be fully impaired for that reporting period. On the contrary, impairment loss is not recognized, if: "i) a player suffers an injury in a reporting period and is temporarily unable to play professional football with the club; or ii) a player suffers a decline in fitness or ability and is not selected for participating in first-team matches."

In this regard, future wages of players are continued, as employee benefits expenses throughout the duration of the player's contract.

According to Maglio and Rey, (Maglio and Rey, 2017), when a player decides to retire, the football team must carry to the income statement, as depreciation\impairment loss of the related intangible asset, all part of non amortised costs. The reason for such an action is that there will be no future economic returns for this player. In case of consensual contract termination (e.g., Juventus F.C. in 2015 with Fernando Llorente) and also when a player is included in the "assets to be sold" (Birmingham F.C. in 2015) the registration is considered acceptable as an internal impairment source.

In relation to the external indicators, Biancone and Solazzi (2012) reveal that a player's underperformance is a reason for potential impairment, although it is difficult to define. Therefore, carrying out an impairment test is important due to the fact that the goals set by the team are not always met (Rangers F.C., 2016). An example of goals setting failure could be that a team qualifies for the Europa League, instead of the Champions league. As a result, impairment test could be considered as the missing link between sport performance and the financial performance. 


\section{Conclusions}

Overall, the current research extends the scholarly conversation regarding how players' registrations are treated in financial reports. It provides accountants with a comprehensive perspective on the application and interpretation of accounting standards and the FFP, regarding the value players' identification and registration. We consider this endeavour appropriate and topical, because FFP has revealed weaknesses and inadequacies in the existing financial reporting model.

As with any other study, this one has some limitations. The first limitation regards the sample size: the sample is significant and appropriate for our study (considering all the football clubs listed on the European stock markets) but limited by the fact that the final composition excludes Turkish and Polish teams due to non-integral application of IAS/IFRS principles (although their financial statements have been studied). In addition, we also exclude another four small-sized companies from the analysis, as their profiles do not match those of the remaining 13 companies. Teams from the Premier League (EPL) and La Liga are also excluded, primarily because they are not part of the STOXX index, which provided the critical selection criteria for this research sample. These criteria represent an important limit in our research sample. The second limitation regards to the information that the data and figures of players' registrations are analyzed as aggregate values, from a club-level perspective. Given the current practices, it is difficult to extract the specific values of individual players from financial statements. In this respect, future research would benefit from focusing on the research methods and techniques in order to provide in-depth reflections of potential discrepancies regarding the treatment of players' registrations in financial reports. The third limitation is the mainly the explorative nature of the research focus, which relied on the available data on the STOXX website.

Nevertheless, by advancing descriptive statistics and their corresponding trends in terms of multiannual rights, the study explores how the performances of professional footballers are exploited (e.g., financial year profit/loss, total assets, and devaluation of multi-year rights). It is a preliminary step toward the clarification of complex issues, analysing the accountability of player registrations. It contemplates concerns regarding to the impairment test within the boundaries of the football industry. As a result, transparent reporting, sustaining the triple bottom line, is required to bridge these accounting inadequacies. Finally, by conducting a three-step analysis of the financial statements of 13 surveyed clubs, this study reveals several discrepancies in relation to the formulated points of analysis, which are:

i) Firstly (e.g., Football clubs comply with the provisions of IAS 36), the study demonstrates that all teams listed on the STOXX index comply with the requirements of IAS 36. On the one hand, this is a positive indication, signaling a minimum form of compliance with the development of transparent and sustainable reporting. On the other hand, there are many issues relating to the players' valuations and the clubs' financial results, as the other two points of analysis underline.

ii) Secondly, in relation to conforming football clubs that also perform the impairment test, the results are rather controversial. The financial statements indicate that the clubs that are included in the STOXX index perform the impairment test, although the numerical results are not always published. Therefore, there is a clear indication that there is lack of directives within IAS 36 regarding the impairment test. The main reason is that IAS 36 requires the performance of the impairment test, but it does not require its disclosure within the financial statements, thus, a greater level of disclosure that will gradually lead to sustainable reporting is necessary (Déjean and Martinez, 2009).

iii) Thirdly, in relation to the football clubs that provide transparent justification for their assets' devaluation, there is lack of verification for several STOXX index teams. There is a rather trivial approach to these devaluations, and there is lack of evidence relating to international consistency. In addition, in this point, we have another gap relating to data disclosure. Paradoxically, certain clubs seem to have a greater level of data disclosure due to national regulations (e.g., FIGC regulations). Thus, these clubs cohesively comply with those regulations that oblige them to prepare a "prospect of multiannual rights movements" report. This type of reporting enables transparent practices, which provide fertile ground for sustainable reporting. This report should accompany, according to FIGC, the club's financial statements. However, it is absent for many of the selected teams. Its absence provides a clear indication that potential future 
sustainable analysis is lacking the necessary disclosure. Therefore, consistent practice of the assets' devaluation is a necessary stepping-stone towards transparent financial reporting.

Explicitly, this study reveals several discrepancies in relation to players' registrations. Some teams included in the STOXX index (see Tables 2, 3 and 4) are less transparent in their statements of financial position's disclosure of player rights' values and of their impairment test findings. These clubs potentially hinder sustainable reporting due to aforementioned disclosure issues. Simultaneously, the same clubs, which are exhibiting a high level of disclosure, are the ones that record a greater increase of their rights' values. Specifically, Juventus seems to be clear in respect to prescriptions. In relation to impairment test information and clarity, AS Roma occupies an intermediate position with respect to other clubs. For Lazio, analysing the declarations and notes, an unspecified value of the impairment emerges. Careful investigation of this value is detectable in financial appendices. Financial appendices for Lazio's case are imposed by FIGC. Therefore, we align with Clarke's (2004) suggestion that the lack of financial guidelines creates the need for stakeholders' identification, harmonisation and engagement. The financial reporting of football clubs is of prominent importance for international disclosure. The break-even result of the FFP is a key element in determining whether to grant a license to participate in the very profitable UEFA club competitions to a particular club. UEFA encourages advanced disclosure, but it has not yet proposed disclosure of information on FFP or of the club-level FFP break-even result. Based on the results of our research, the UEFA should take this necessary step regarding this aspect of reporting. Such an initiative would help stakeholders increase the social profile of their teams, as well as their financial profile. UEFA also recognises that the value of the football clubs is not limited to financial profitability, but it stands out as a valuable social factor benefiting local communities. Increasing football club revenues coupled with persistent financial management deficits has resulted in increased demand for accountability, disclosure information and control that have wider impacts on society. Nevertheless, it is noteworthy that over the years examined only a few teams disclosed higher profits than costs. Such practices undermine the social aspect of this game, underestimate its novel character, and sport value. They also limit the reservoir of potential and diverse investors, as they fail to demonstrate the integration of communities' interest to local football clubs.

On the one hand, there are teams like Borussia Dortmund, a rare example, reporting revenues higher than costs. In this category, we also include Parken Sports, AFC Ajax and Lazio, although they did not do so consistently for all the years covered by this study. Specifically, Parken Sports had a bad financial year in 2015. Likewise, AFC Ajax did not break-even in 2015 or 2016. Finally, Lazio reported losses in 2012 and 2013. Nevertheless, in general, this group of teams exhibits a healthy economic profile enabling financial and social value for the local stakeholders.

On the other hand, Juventus managed to reach the break-even point for the financial year 2015, overcoming a financial period solely characterized by negative results. Olympique Lyonnais reached the break-even point one year later in 2016. Similarly, Aalborg and Sport Lisboa went from negative results to positive results in 2014. Despite an improving trend, AS Roma has not yet improved its results. Thus, the break-even threshold remains a distant horizon for several teams in this group and jeopardises supporters' trust.

Overall, this study critically discusses the financial and economic communication prepared by football clubs. It concludes that financial statements need to provide contextual disclosure to the information disclosed to investors for sustainable financing and social impact. IAS/IFRS accounting standards do not fully comply with all companies' typologies with a consistent business model. Based on our research, this is also the case today, as we fail to recognize sustainable growth plans, besides rare examples, which require profitability and business investment. The financial statements from the Italian football clubs, which display ambiguous information, underline a good example of such practices. As a result, FIGC undertook a significant initiative to bridge this informational gap (FIGC, 2015) by requiring the creation of an additional statement identifying the importance of recognizing the devaluation of multi-year rights. This initiative, involving a greater degree of disclosure among the teams that have followed it, should also be undertaken internationally; in particular it could be considered as a solution to the nonadherence of IAS/IFRS to the football sector. As noted, there are discrepancies between UEFA regulations 
and IAS/IFRS standards; in terms of disclosure, the FIGC example could increase the current lack of international transparency in the football sector.

\section{References}

1. Abdel-Khalik, A. R. (2003). Self-sorting, incentive compensation and human-capital assets. European Accounting Review, 12(4), 661-697.

2. Amir, E., \& Livne, G. (2005). Accounting, valuation and duration of football player contracts. Journal of Business Finance \& Accounting, 32(3/4), 549-586.

3. Biancone, P. P., \& Solazzi, A. (2012). Financial communication in professional football clubs. Economia Aziendale Online, 3(1), 153-174.

4. Bloomfield, R., Nelson, M. W., \& Soltes, E. (2015). Gathering data for financial reporting research. Paper prepared for the 2015 Journal of Accounting Research Conference, available on the internet at: https://research.chicagobooth.edu/ /media/9426d33275d941968d29f45e0086989b.pdf Accessed 15.03.2018

5. Blumrodt, J., Desbordes, M., \& Bodin, D. (2013). Professional football clubs and corporate social responsibility. Sport, Business and Management: An International Journal, 3(3), 205-225. DOI: 10.1108/SBM-04-2011-0050.

6. Breitbarth, T., \& Harris, P. (2008). The role of corporate social responsibility in the football business: Towards the development of a conceptual model. European Sports Management Quarterly, 8(2), 179-206.

7. Brummet, R. L., Flamholtz, E. G., \& Pyle, W. C. (1968). Human Resource measurement - A challenge for accountants. The Accounting Review, 43(2), 217-224.

8. CIES Football Observatory. (2017). Transfer values updated: who are the most expensive players?. available on the internet at: http://www.football-observatory.com/IMG/sites/b5wp/2016/172/en/ Accessed 02.06.2017.

9. Clarke, T. (2004). Cycles of crisis and regulation: The enduring agency and stewardship problems of corporate governance. Corporate Governance: An International Review, 12(2), 153-161.

10.Chee Chiu Kwok, W., \& Sharp, D. (2005). Power and international accounting standard setting: Evidence from segment reporting and intangible assets projects. Accounting, Auditing \& Accountability Journal, 18(1), 74-99. DOI: 10.1108/09513570510584665.

11.Cooper, C., \& Johnston, J. (2012). Vulgate accountability - insights from the world of football. Accounting, Auditing \& Accountability Journal, 25(4), 602-634.

12.Cooper, C., \& Joyce, Y. (2013). Insolvency practice in the field of football. Accounting, Organisations and Society, 38(2), 108-129. DOI: 10.1016/j.aos.2012.12.001

13.Déjean, F., \& Martinez, I. (2009). Environmental disclosure and the cost of equity: the French case. Accounting in Europe, 6(1), 57-80.

14.Dimitropoulos, P. E., \& Koumanakos, E. (2015). Intellectual capital and profitability in European football clubs. International Journal of Accounting, Auditing and Performance Evaluation, 11(2), 202-220.

15.Elfaki, A. A. A., \& Hammad, S. M. E. (2015). The impact of the application of Fair Value Accounting on the quality of accounting information. An empirical study on a group of companies listed on the Khartoum stock exchange. International Journal of Academic Research in Accounting, Finance and Management Sciences, 5(1), 148-160.

16.FIGC. (2015). Football Report 2015. Available on the internet at: http://www.figc.it/other/ ReportCalcio2015/FIGC_Report_ENG_WEB.pdf Accessed 15.10.2015.

17.Fiori, G. (2003). La valutazione dei diritti pluriennali alle prestazioni degli sportivi professionisti: una possibile metodologia. Rivista Italiana di Ragioneria ed Economia Aziendale; 103 (7/8): 314-330.

18.Forker, J. (2005). Discussion of accounting, valuation and duration of football player contracts. Journal of Business Finance \& Accounting, 32(3/4), 587-598.

19.Fort, R., \& Quirk, J. (2004). Owner objectives and competitive balance. Journal of Sport Economics, $5(1), 20-32$.

20.Ganga, M., Kalaiselvan, P., \& Suriya, R. (2015). Evaluation of financial performance. International Journal of Scientific and Research Publications, 5(4), 1-7. 
21.Gazzola, P., \& Amelio, S. (2015). The value of human resources in non-profit organisations: The Italian situation. Economia Aziendale Online, 6(1), 1-9.

22.Gazzola, P., \& Amelio, S. (2016). Impairment test in the football team financial reports. ProcediaSocial and Behavioral Sciences, 220, 105-114.

23.Gazzola, P., Ratti, M., \& Amelio, S. (2017). CSR and Sustainability Report for Nonprofit Organizations. An Italian Best Practice. Management Dynamics in the Knowledge Economy, 5(3), 355-376.

24.Geeraert, A., Scheerder, J., \& Bruyninckx, H. (2013). The governance network of European football: Introducing new governance approaches to steer football at the EU level. International Journal of Sport Policy and Politics, 5(1), 113-132.

25.Gelmini, L. (2014). Le società di calcio professionistiche nella prospettiva dell'economia d'azienda. Modelli di bilancio e valore economico dei club. Torino: Giuffrè editore.

26.Giulianotti, R. (2012). Football. New York: John Wiley \& Sons Ltd.

27.Guthrie, J., Ricceri, F., \& Dumay, J. (2012). Reflections and projections: a decade of intellectual capital accounting research. The British Accounting Review, 44(2), 68-82.

28. Hassine, N. M., \& Jilani, F. (2017). Earnings Management Behavior with Respect to Goodwill Impairment Losses under IAS 36: The French Case. International Journal of Academic Research in Accounting, Finance and Management Sciences, 7(2), 177-196.

29. Hoogendoorn, M. (2006). International accounting regulation and IFRS implementation in Europe and beyond-experiences with first-time adoption in Europe. Accounting in Europe, 3(1), 23-26. DOI: 10.1080/09638180600920087.

30.Huikku, J., Mouritsen, J., \& Silvola, H. (2017). Relative reliability and the recognisable firm: Calculating goodwill impairment value. Accounting, Organisations and Society, 56(1), 68-83. DOI: 10.1016/j.aos.2016.03.005.

31.Husmann, S., \& Schmidt, M. (2008). The discount rate: A note on IAS 36. Accounting in Europe, $5(1), 49-62$.

32.King, A. (2017). The European ritual: Football in the new Europe. London and New York: Routledge.

33.Lev, B. (2001). Intangibles: Management, measurement and reporting. Washington DC: Brooking Institution Press.

34.Madden, P. (2012). Welfare economics of 'financial fair play' in a sports league with benefactor owners. Journal of Sports Economics, 16(2), 159-184.

35.Maglio, R., \& Rey, A. (2017). The impairment test for football players: The missing link between sports and financial performance? Palgrave Communications, 3(17055). DOI: 10.1057/palcomms.2017.55.

36. Mancin, M. (2009). Il bilancio delle società sportive professionistiche. Normativa civilistica, principi contabili nazionali e internazionali (IAS/IFRS). Padova: CEDAM.

37.Mazzi, F., Liberatore, G., \& Tsalavoutas, I. (2016). Insights on CFOs' perceptions about impairment testing under IAS 36. Accounting in Europe, 13(3), 353-379.

38. Michie, J., \& Verma, S. (1999). Is Paul Ince an asset or a liability? Accounting and governance issues in football. In Sean, H., Michie, J., \& Oughton, C. (Ed.). A Game of Two Halves? The Business 0 Football. London: Mainstream.

39.Morrow, S. (1996). Football players as human assets. Measurement as the critical factor in recognition: A case study. Journal of Human Resource Costing and Accounting, 1(1), 75-97.

40.Morrow, S. (1999). The New Business of Football. UK: MacMillan Business.

41.Morrow, S. (2013). Football club financial reporting: Time for a new model. Sport, Business and Management: An International Journal, 3(4), 297-311.

42.Morrow, S. (2014). Financial Fair Play-Implications for Football Club Financial Reporting. Edinburgh: ICAS.

43.Müller, J. C., Lammert, J., \& Hovemann, G. (2012). The financial fair play regulations of UEFA: An adequate concept to ensure the long-term viability and sustainability of European club football?. International Journal of Sport Finance, 7(2), 117. 
44.Niemann, A., Garcia, B., \& Grant, W. (2011). Introduction: The Transformation of European Football. In Niemann, A., Garcia, B., \& Grant, W. (Ed.). The Transformation of European Football: Towards the Europeanisation of the National Game (pp. 1-19), Manchester: Manchester University Press.

45.Oliveira, L., Rodrigues, L. L., \& Craig, R. (2010). Intangible assets and value relevance: Evidence from the Portuguese stock exchange. The British Accounting Review, 42(4), 241-252.

46.Oprean, V. B., \& Oprisor, T. (2014). Accounting for soccer players: Capitalization paradigm vs. Expenditure. Procedia Economics and Finance, 15, 1647-1654. DOI: 10.1016/S2212-5671(14)00636-4.

47.Patton, J., \& Zelenka, I. (1997). An empirical analysis of the determinants of the extent of disclosure in annual reports of joint stock companies in the Czech Republic. European Accounting Review, 6(4), 605-626.

48.Pavlović, V., Milačić, S., \& Ljumović, I. (2014). Controversies about the accounting treatment of transfer fee in the football industry. Management, 70(1), 17-24. DOI: 10.7595/management.fon.2014.0001.

49.Preuss, H., Haugen, K., \& Schubert, M. (2014). UEFA financial fair play: the curse of regulation. European Journal of Sport Studies, 2(1), 33-51.

50.Powell, S. (2003). Accounting for intangible assets: current requirements, key players and future directions. European accounting review, 12(4), 797-811.

51.Qureshi, M. I. (2017). The value relevance of intangibles: some evidence on industry sector, firm performance and size effects. International Journal of Accounting, Auditing and Performance Evaluation, 13(3), 293-307.

52.Regoliosi, C. (2016). The accounting treatments in professional football clubs in Italy from a business model perspective. Rivista Italiana di Ragioneria e di Economia Aziendale, 5(6), 7.

53.Risaliti, G., \& Verona, R. (2012). Players' registration rights in the financial statements of the leading Italian clubs. Accounting, Auditing \& Accountability Journal, 26(1), 16-47.

54.Rouvrais-Charron, C., \& Durand, C. (2009). European football under close scrutiny. International Journal of Sports Marketing \& Sponsorship, 10(3), 33-46.

55.Rowbottom, N. (2002). The application of intangible asset accounting and discretionary policy choices in the UK football industry. The British Accounting Review, 34(4), 335-355.

56.Sahut, J. M., Boulerne, S., \& Teulon, F. (2011). Do IFRS provide better information about intangibles in Europe? Review of Accounting and Finance, 10(3), 267-290. DOI: 10.1108/1475770111 1155798.

57.Scarpello, V., \& Theeke, H.A. (1989). Human resource accounting: a measured critique. Journal of Accounting Literature, 8, 265-280.

58.Simga-Mugan, C., \& Hosal-Akman, N. (2005). Convergence to international financial reporting standards: the case of Turkey. International Journal of Accounting, Auditing and Performance Evaluation, 2(1-2), 127-139.

59.Solntsev, I. V., \& Chuchina, E. A. (2017). Transformation of financial statements of the Russian football clubs in accordance with international financial reporting standards. Digest Finance, 2, 242.

60.Stolowy, H., \& Jeny-Cazavan, A. (2001). International accounting disharmony: The case of intangibles. Accounting, Auditing \& Accountability Journal, 14(4), 477-497. DOI: 10.1108/09513570110403470.

61.Statista. (2017). Media rights value of the leading football leagues in Europe in 2016/2017 (in million euros). Available on the internet at: https://www.statista.com/statistics/627303/media-rightsvalue-of-leading-european-football-leagues/ Accessed 09.06.2017.

62.Statista. (2018a). Revenue of the top European soccer leagues (Big Five*) from 2006/07 to 2017/18 (in billion euros). Available on the internet at: https://www.statista.com/statistics/261225/topeuropean-soccer-leagues-big-five-revenue/ Accessed 05.04.2018.

63.Statista. (2018b). Total transfer fee spending of big-5 league soccer clubs from 2010 to 2017 (in million euros). Available on the internet at: https://www.statista.com/statistics/742926/big-5-soccerleague-transfer-fee-spending/ Accessed 05.04.2018.

64.Storm, R. (2012). The need for regulating professional soccer in Europe: A soft budget constraint approach argument. Sport, Business and Management: An International Journal, 2(1), 21-38.

65.Taylor, M. (2013). The Association Game: A History of British Football. London: Routledge. 
66.UEFA. (2002). UEFA Club Licensing System - Season 2004/05. Version 1.0 E, Nyon: UEFA.

67.UEFA. (2009). Financial fair play. Available on the internet at: http://www.uefa.org/protectingthe-game/club-licensing-and-financial-fair-play/ Accessed 10.10.2015.

68.UEFA. (2012). Financial Fair Play and Club Licensing Regulations. Edition 2012, Nyon: UEFA.

69.UEFA. (2013). The European Club Licensing Benchmarking Report Financial Year 2011. Nyon: UEFA.

70.UEFA. (2015). Financial fair play: All you need to know. Available on the internet at: http://www.uefa.com/community/news/newsid=2064391.html Accessed 10.10.2015.

71.UEFA. (2015b). Club licensing. Available on the internet at: https://www.uefa.com/Multimedia Files/Download/uefaorg/FinancialFairPlay/02/32/60/65/2326065_DOWNLOAD.pdf Accessed 11.06.2019.

72.Van Beest, F., Braam, G., \& Boelens, S. (2009). Quality of financial reporting: Measuring qualitative characteristics. NiCE Working Paper 09-108, April 2009, Nijmegen Center for Economics (NiCE), Institute for Management Research, Radboud University Nijmegen, The Netherlands.

73.Vernhet, A., \& Augè, B. (2010). Professional Players: Specific Intangible Assets. Prague: EASM.

74.Vernhet, A., \& Bernard, A. (2010). Professional Players: Specific Intangible Assets. Prague: EASM.

75.Vishnani, S., \& Shah, B. K. (2008). Value relevance of published financial statements-with special emphasis on impact of cash flow reporting. International Research Journal of Finance and Economics, 17(1), 84-90.

76.Walters, G., \& Chadwick, S. (2009). Corporate citizenship in football: Delivering strategic benefits through stakeholder engagement. Management Decision, 47(1), 51-66.

77.Wyatt, A. (2005). Accounting recognition of intangible assets: Theory and evidence on economic determinants. The Accounting Review, 80(3), 967-1003.

78. Wyatt, A. (2008). What financial and non-financial information on intangibles is value-relevant? A review of the evidence. Accounting and Business Research, 38(3), 217-256.

\section{List of abbreviations}

CSR, Corporate Social Responsibility

$\mathrm{CMB}$, Capital Markets Board

EPL, English Premier League

EU, European Union

FIFA, Fédération Internationale de Football Association

FIGC, Federazione Italiana Giuoco Calcio

FSB, Financial Supervisory Body

FFP, Financial Fair Play

GRI, Global Reporting Initiative

IAS, International Accounting Standards

IFRS, International Financial Reporting Standards

NGO, Non-governmental organization

POA, Public Oversight Accounting and Auditing Standards Authority

TAS, Turkish Accounting Standards

UEFA, Union of European Football Associations 